\title{
SISALv2: a comprehensive speleothem isotope database with multiple age-depth models
}

\author{
Laia Comas-Bru $^{1}$, Kira Rehfeld ${ }^{2}$, Carla Roesch $^{2}$, Sahar Amirnezhad-Mozhdehi ${ }^{3}$, Sandy P. Harrison ${ }^{1}$, \\ Kamolphat Atsawawaranunt ${ }^{1}$, Syed Masood Ahmad ${ }^{4}$, Yassine Ait Brahim ${ }^{5, a}$, Andy Baker ${ }^{6}$, \\ Matthew Bosomworth $^{1}$, Sebastian F. M. Breitenbach ${ }^{7}$, Yuval Burstyn ${ }^{8}$, Andrea Columbu ${ }^{9}$, \\ Michael Deininger ${ }^{10}$, Attila Demény ${ }^{11}$, Bronwyn Dixon ${ }^{1,12}$, Jens Fohlmeister ${ }^{13}$, István Gábor Hatvani ${ }^{11}$, \\ Jun Hu ${ }^{14}$, Nikita Kaushal ${ }^{15}$, Zoltán Kern ${ }^{11}$, Inga Labuhn ${ }^{16}$, Franziska A. Lechleitner ${ }^{17}$, \\ Andrew Lorrey ${ }^{18}$, Belen Martrat ${ }^{19}$, Valdir Felipe Novello ${ }^{20}$, Jessica Oster ${ }^{21}$, Carlos Pérez-Mejías ${ }^{5}$, \\ Denis Scholz $^{10}$, Nick Scroxton ${ }^{22}$, Nitesh Sinha ${ }^{23,24}$, Brittany Marie Ward ${ }^{25}$, Sophie Warken ${ }^{26}$, \\ Haiwei Zhang ${ }^{5}$, and SISAL Working Group members ${ }^{+}$ \\ ${ }^{1}$ School of Archaeology, Geography, and Environmental Science, University of Reading, Reading, UK \\ ${ }^{2}$ Institute of Environmental Physics and Interdisciplinary Center for Scientific Computing, \\ Heidelberg University, Heidelberg, Germany \\ ${ }^{3}$ School of Geography, University College Dublin, Belfield, Dublin 4, Ireland \\ ${ }^{4}$ Department of Geography, Faculty of Natural Sciences, Jamia Millia Islamia, New Delhi, India \\ ${ }^{5}$ Institute of Global Environmental Change, Xi' an Jiaotong University, Xi' an, Shaanxi, China \\ ${ }^{6}$ Connected Waters Initiative Research Centre, UNSW Sydney, Sydney, New South Wales 2052, Australia \\ ${ }^{7}$ Department of Geography and Environmental Sciences, Northumbria University, Newcastle upon Tyne, UK \\ ${ }^{8}$ The Fredy and Nadine Herrmann Institute Earth Sciences, The Hebrew University of Jerusalem, \\ The Edmond J. Safra Campus, Jerusalem 9190401, Israel \\ ${ }^{9}$ Department of Biological, Geological and Environmental Sciences (BiGeA), University of Bologna, \\ Via Zamboni 67, 40126, Bologna, Italy \\ ${ }^{10}$ Institute for Geosciences, Johannes Gutenberg University Mainz, \\ J.-J.-Becher-Weg 21, 55128 Mainz, Germany \\ ${ }^{11}$ Institute for Geological and Geochemical Research, Research Centre for Astronomy and Earth Sciences, \\ 1112, Budaörsi út 45, Budapest, Hungary \\ ${ }^{12}$ School of Geography, University of Melbourne, Parkville 3010 VIC, Australia \\ ${ }^{13}$ Potsdam Institute for Climate Impact Research PIK, Potsdam, Germany \\ ${ }^{14}$ Department of Earth, Environmental and Planetary Sciences, Rice University, Houston, TX 77005, US \\ ${ }^{15}$ Asian School of the Environment, Nanyang Technological University, Singapore \\ ${ }^{16}$ Institute of Geography, University of Bremen, Celsiusstraße 2, 28359 Bremen, Germany \\ ${ }^{17}$ Department of Earth Sciences, University of Oxford, Oxford OX1 3AN, UK \\ ${ }^{18}$ National Institute of Water and Atmospheric Research, Auckland, 1010, New Zealand \\ ${ }^{19}$ Department of Environmental Chemistry, Spanish Council for Scientific Research (CSIC), \\ Institute of Environmental Assessment and Water Research (IDAEA), Barcelona, Spain \\ ${ }^{20}$ Institute of Geoscience, University of São Paulo, São Paulo, Brazil \\ ${ }^{21}$ Department of Earth and Environmental Sciences, Vanderbilt University, Nashville, TN 37240, USA \\ ${ }^{22}$ School of Earth Sciences, University College Dublin, Belfield, Dublin 4, Ireland \\ ${ }^{23}$ Center for Climate Physics, Institute for Basic Science, Busan, 46241, Republic of Korea \\ ${ }^{24}$ Pusan National University, Busan, 46241, Republic of Korea \\ ${ }^{25}$ Environmental Research Institute, University of Waikato, Hamilton, New Zealand \\ ${ }^{26}$ Institute of Earth Sciences and Institute of Environmental Physics, \\ Heidelberg University, Heidelberg, Germany \\ ${ }^{a}$ now at: Department of Environmental Sciences, University of Basel, Basel, Switzerland
}




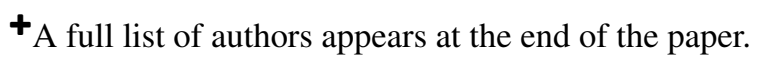

Correspondence: Laia Comas-Bru (1.comasbru@reading.ac.uk)

Received: 17 February 2020 - Discussion started: 13 March 2020

Revised: 5 August 2020 - Accepted: 30 August 2020 - Published: 27 October 2020

\begin{abstract}
Characterizing the temporal uncertainty in palaeoclimate records is crucial for analysing past climate change, correlating climate events between records, assessing climate periodicities, identifying potential triggers and evaluating climate model simulations. The first global compilation of speleothem isotope records by the SISAL (Speleothem Isotope Synthesis and Analysis) working group showed that age model uncertainties are not systematically reported in the published literature, and these are only available for a limited number of records (ca. $15 \%, n=107 / 691$ ). To improve the usefulness of the SISAL database, we have (i) improved the database's spatio-temporal coverage and (ii) created new chronologies using seven different approaches for agedepth modelling. We have applied these alternative chronologies to the records from the first version of the SISAL database (SISALv1) and to new records compiled since the release of SISALv1. This paper documents the necessary changes in the structure of the SISAL database to accommodate the inclusion of the new age models and their uncertainties as well as the expansion of the database to include new records and the qualitycontrol measures applied. This paper also documents the age-depth model approaches used to calculate the new chronologies. The updated version of the SISAL database (SISALv2) contains isotopic data from 691 speleothem records from 294 cave sites and new age-depth models, including age-depth temporal uncertainties for 512 speleothems. SISALv2 is available at https://doi.org/10.17864/1947.256 (Comas-Bru et al., 2020a).
\end{abstract}

\section{Introduction}

Speleothems are a rich terrestrial palaeoclimate archive that forms from infiltrating rainwater after it percolates through the soil, epikarst and carbonate bedrock. In particular, stable oxygen and carbon isotope $\left(\delta^{18} \mathrm{O}, \delta^{13} \mathrm{C}\right)$ measurements made on speleothems have been widely used to reconstruct regional and local hydroclimate changes.

The Speleothem Isotope Synthesis and Analyses (SISAL) working group is an international effort under the auspices of Past Global Changes (PAGES) to compile speleothem isotopic records globally for the analysis of past climates (Comas-Bru and Harrison, 2019). The first version of the SISAL database (Atsawawaranunt et al., 2018a, b) contained 381 speleothem records from 174 cave sites and has been used for analysing regional climate changes (Braun et al., 2019a; Burstyn et al., 2019; Comas-Bru and Harrison, 2019; Deininger et al., 2019; Kaushal et al., 2018; Kern et al., 2019; Lechleitner et al., 2018; Oster et al., 2019; Zhang et al., 2019). The potential for using the SISAL database to evaluate climate models was explored using an updated version of the database (SISALv1b; Atsawawaranunt et al., 2019) that contains 455 speleothem records from 211 sites (Comas-Bru et al., 2019).

SISAL is continuing to expand the global database by including new records (Comas-Bru et al., 2020a). Although most of the records in SISALv2 (79.7\%; Fig. 1a) have been dated using the generally very precise, absolute radiometric ${ }^{230} \mathrm{Th} / \mathrm{U}$ dating method, a variety of age-modelling approaches were employed (Fig. 1b) in constructing the orig- inal records. The vast majority of records provide no information on the uncertainty of the age-depth relationship. However, many of the regional studies using SISAL pointed to the limited statistical power of analyses of speleothem records because of the lack of temporal uncertainties. For example, these missing uncertainties prevented the extraction of underlying climate modes during the last 2000 years in Europe (Lechleitner et al., 2018). To overcome this limitation, we have developed additional age-depth models for the SISALv2 records (Fig. 2) in order to provide robust chronologies with temporal uncertainties. The results of the various age-depth modelling approaches differ because of differences in their underlying assumptions. We have used seven alternative methods: linear interpolation, linear regression, Bchron (Haslett and Parnell, 2008), Bacon (Blaauw and Christen, 2011; Blaauw et al., 2019), OxCal (Bronk Ramsey, 2008, 2009; Bronk Ramsey and Lee, 2013), COPRA (Breitenbach et al., 2012) and StalAge (Scholz and Hoffmann, 2011). Comparison of these different approaches provides a robust measure of the age uncertainty associated with any specific speleothem record.

\section{Data and methods}

\subsection{Construction of age-depth models: the SISAL chronology}

We attempted to construct age-depth models for 533 entities in an automated mode. For eight records, this automated construction failed for all methods. For these records we provide 
(a)

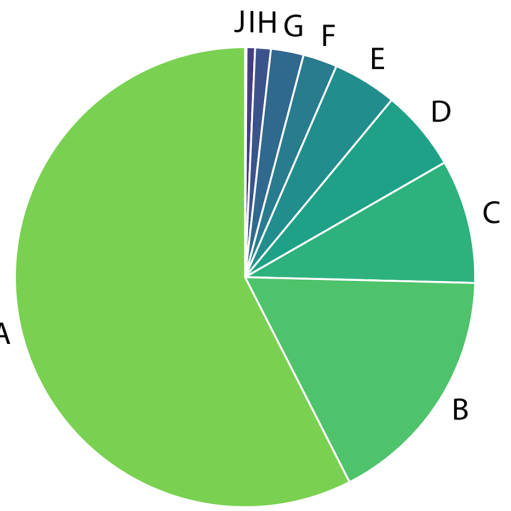

\section{Date types}

A : MC-ICP-MS Th-U $(57.5 \%)$

$B: \operatorname{TIMS}(17.1 \%)$

C : event; actively forming (8.7\%)

D : ICP-MS Th-U Other (5.7\%)

E : event; laminations $(4.5 \%)$

$\mathrm{F}: \mathrm{C} 14(2.4 \%)$

$\mathrm{G}:$ Th-U unspecified $(2.3 \%)$

$\mathrm{H}$ : Alpha Th-U (1.1\%)

I : multiple methods (0.6\%)

$\mathrm{J}$ : other $(0.1 \%)$

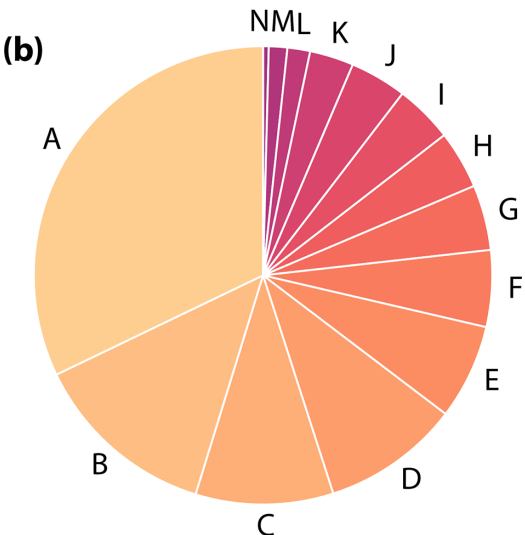

\section{Age model types}

A : linear between dates ( $32.1 \%)$

B : StalAge (13.1\%)

C : COPRA $(9.7 \%)$

D : unknown $(9.7 \%)$

E : linear regression (6.7\%)

$\mathrm{F}$ : other $(5.4 \%)$

$\mathrm{G}:$ Bayesian $(4.6 \%)$

$\mathrm{H}$ : OxCal $(4.1 \%)$

I: polynomial fit (4.1\%)

$\mathrm{J}$ : combination of methods ( $4 \%$ )

$\mathrm{K}$ : no original age model (3.1\%)

$\mathrm{L}$ : StalAge and other (1.6\%)

$\mathrm{M}$ : polynomial fit omitting outliers (1.3\%)

$\mathrm{N}$ : Clam (0.4\%)

Figure 1. Summary of the dating information on which the original age-depth models are based (a) and the original age-depth model types (b) present in SISALv2.

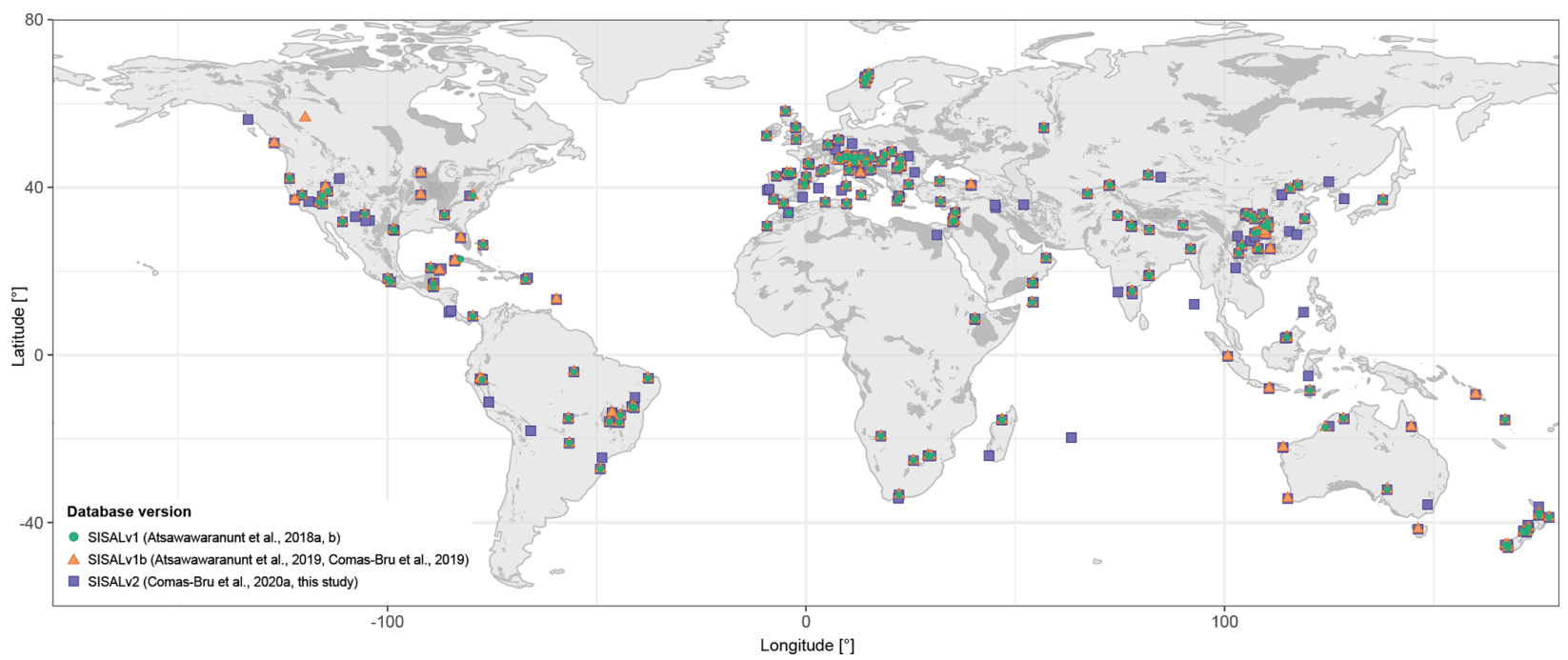

Figure 2. Cave sites included in the version 1, $1 \mathrm{~b}$ and 2 of the SISAL database on the World Karst Aquifer Map (WOKAM; Goldscheider et al., 2020). 
manually constructed chronologies where no age model previously existed and added a note in the database with details on the construction procedure. Age models for 21 records were successfully computed but later dropped in the screening process due to inconsistent information or incompatibility for an automated routine. In total, we provide additional chronologies for 512 speleothem records in SISALv2.

The SISAL chronology provides alternative age-depth models for SISAL records that are not composites (i.e. time series based on more than one speleothem record), that have not been superseded in the database by a newer entity and which are purely ${ }^{230} \mathrm{Th} / \mathrm{U}$ dated. We therefore excluded records for which the chronology is based on lamina counting, radiocarbon ages or a combination of methods. This decision was based on the low uncertainties of the age-depth models based on lamina counting and the challenge of reproducing age-depth models based on radiocarbon ages. We made an exception with the case of entity_id 163 (Talma et al., 1992), which covers two key periods - the mid-Holocene and the Last Glacial Maximum - at high temporal resolution. In this case, we calculated a new SISAL chronology based on the provided ${ }^{230} \mathrm{Th} / \mathrm{U}$ dates but did not consider the uncorrected ${ }^{14} \mathrm{C}$ ages upon which the original age-depth model is based. We also excluded records for which isotopic data are not available (i.e. entities that are part of composites) and entities that are constrained by less than three dates. Additionally, the dating information for 23 entities shows hiatuses at the top and bottom of the speleothem that are not constrained by any date. For these records, we partially masked the new chronologies to remove the unconstrained section(s). Original dates were used without modification in the age-depth modelling.

To allow a comprehensive cross-examination of uncertainties, seven age-depth modelling techniques were implemented here across all selected records. Due to the high number of records $(n=533)$, all methods were run in batch mode. A preliminary study using the database version v1b demonstrated the feasibility of the automated construction and evaluation of age-depth models using a subset of records and methods (Roesch and Rehfeld, 2019). Further details on the evaluation of the updated age-depth models are provided in Sect. 3.2. The seven different methods are briefly described below. All methods assume that growth occurred along a single growth axis. For one entity, where it was previously known that two growth axes exist, we added an explanatory statement in the database. All approaches except StalAge produce Monte Carlo (MC) iterations of the age-depth models. We aimed to provide 1000 MC iterations for each new SISALv2 chronology at https://doi.org/10.5281/zenodo.3816804 (Rehfeld et al., 2020), but this was not always possible because some records $(n=12)$ yield a substantial number of non-monotonic ensembles that were not kept.

Major challenges arise through hiatuses (growth interruptions) and age reversals. We developed a workflow to deal with records with known hiatuses that allowed the construction of age-depth models for $20 \%$ of the records with one or more hiatuses (Roesch and Rehfeld, 2019; details below for each age-depth modelling technique). Regarding the age reversals, we distinguish between tractable reversals (with overlapping confidence intervals) and non-tractable reversals (i.e. where the 2-sigma dating uncertainties do not overlap) following the definition of Breitenbach et al. (2012). Details such as the hiatus treatment and outlier age modification are recorded in a $\log$ file created when running the age models. We followed the original author's choices regarding date usage. If an age was marked as "not used" or "usage unknown", we did not consider this in the construction of the new chronologies except in OxCal, where dates with "usage unknown" were considered.

1. Linear interpolation (lin_interp_age) between radiometric dates is the classic approach for age-depth model construction for palaeoclimate archives and was used in $32.1 \%$ of the original age-depth models in SISALv2. Here, we extend this approach and calculate the age uncertainty by sampling the range of uncertainty of each ${ }^{230} \mathrm{Th} / \mathrm{U}$ age 2000 times, assuming a Gaussian distribution. This approach is consistent with the implementation of linear interpolation in CLAM (Blaauw, 2010) and COPRA (Breitenbach et al., 2012). Linear interpolation was implemented in R (R Core Team, 2019), using the approxextrap () function in the Hmisc package. We included an automated reversal check that increases the dating uncertainties until a monotonic age model is achieved, similar to that of StalAge (Scholz and Hoffmann, 2011). Hiatuses are modelled following the approach of Roesch and Rehfeld (2019), where rather than modelling each segment separately, synthetic ages with uncertainties spanning the entire hiatus duration are introduced for use in age-depth model construction. These synthetic ages are removed after agedepth model construction. Linear interpolation was applied to $80 \%(n=408 / 512)$ of the SISAL records for which new chronologies were developed.

2. Linear regression (lin_reg_age) provides a single bestfit line through all available radiometric ages assuming a constant growth rate. Linear regression was used in $6.7 \%$ of the original SISALv2 age models. As with linear interpolation, age uncertainties are based on randomly sampling the U-series dates to produce 2000 age-depth models (i.e. ensembles). Temporal uncertainties are then given by the uncertainty of the medianbased fit to each ensemble member. If hiatuses are present, the segments in-between were split at the depth of the hiatus without an artificial age. The method is implemented in R using the $\operatorname{lm}()$ function from the base package. Linear regression was applied to $36 \%$ $(n=185 / 512)$ of the SISAL records for which new chronologies were developed. 
3. Bchron (Bchron_age) is a Bayesian method based on a continuous Markov processes (Haslett and Parnell, 2008) and is available as an $\mathrm{R}$ package (Parnell, 2018). This method was originally used for only one speleothem record in SISALv2. Since Bchron cannot handle hiatuses, we implemented a new workflow that adds synthetic ages with uncertainties spanning the entire hiatus duration (Roesch and Rehfeld, 2019), as performed with linear interpolation, StalAge and our implementation of COPRA. Bchron provides age-depth model ensembles, of which we have kept the last 2000. We calculate the age uncertainties from the spread of the individual ensembles. Here we use the function bchron() with jitter.positions=true to mitigate problems due to rounded-off depth values. This method has been applied to $83 \%(n=426 / 512)$ of the SISAL records for which new chronologies were developed.

4. Bacon (Bacon_age) is a semi-parametric Bayesian method based on autoregressive gamma processes (Blaauw and Christen, 2011; Blaauw et al., 2019). It was used in three of the original chronologies in SISALv2. The $\mathrm{R}$ package rBacon can handle both outliers and hiatuses, and apart from giving the median age-depth model, it also returns the Monte Carlo realizations (i.e. ensembles), from which the median age-depth model is calculated. During the creation of the SISAL chronologies, the existing rBacon package (version 2.3.9.1) was updated to improve the handling of stalagmite growth rates and hiatuses. We use this revised version, available on CRAN (https://cran. r-project.org/web/packages/rbacon/index.html, last access: 31 January 2020), to provide a median age-depth model and an ensemble of age model realizations for $65 \%(n=335 / 512)$ of the SISAL records for which new chronologies were developed.

5. OxCal (Oxcal_age) is a Bayesian chronological modelling tool that uses Markov chain Monte Carlo (Bronk Ramsey, 2009). This method was used in $4.1 \%$ of the original SISALv2 chronologies. OxCal can deal with hiatuses and outliers and accounts for the non-uniform nature of the deposition process (Poisson process using the P_Sequence command). Here we used the analysis module of $\mathrm{OxCal}$ version 4.3 with a default initial interpolation rate value of 1 and an initial model rigidity $(k)$ value of $k_{0}=1$ with a uniform distribution from 0.01 to 100 for the range of $k / k_{0}\left(\log 10\left(k / k_{0}\right)=(-2,2)\right)$ (Christopher Bronk Ramsey, personal communication, 2019). The initial value of the interpolation rate determines the number of points between any two dates for which an age will be calculated. We subsequently linearly interpolated the age-depth model to the depths of individual isotope measurements. Where multiple dates are given for the same depth for any given entity, the date with the smallest uncertainty was used to construct the SISAL chronology. In the case of asymmetric uncertainties in the dating table, the largest uncertainty value was chosen. We kept the last 2000 realizations of the age-depth models for each entity. We calculate the age uncertainties from the spread of the individual ensembles. Details of the workflow used to construct these chronologies are available in AmirnezhadMozhdehi and Comas-Bru (2019). OxCal chronologies are available for $21 \%(n=106 / 512)$ of the SISAL records for which new chronologies were developed.

6. COPRA (copRa_age) is an approach based on interpolation between dates (Breitenbach et al., 2012) and was used for $9.7 \%$ of the original SISALv2 chronologies. COPRA is available as a MATLAB package in Rehfeld et al. (2017) with a graphical user interface (GUI) that has interactive checks for reversals and hiatuses. The MATLAB version can handle multiple hiatuses and (to some extent) layer-counted segments. However, age reversals can occur near short-lived hiatuses. To overcome this, we implemented a new workflow in R that adds artificial dates at the location of the hiatuses and prevents the creation of age reversals (Roesch and Rehfeld, 2019) as done with linear interpolation, StalAge and Bchron. Additionally, we also incorporated an automated reversal check similar to that already embedded into StalAge (Scholz and Hoffmann, 2011). This R version, copRa, uses the default piecewise cubic Hermite interpolation (pchip) algorithm in $\mathrm{R}$ without consideration of layer counting. We calculate the age uncertainties from the spread of the individual ensembles. This approach was used for $76 \%(n=389 / 512)$ of the SISAL records for which new chronologies were developed.

7. StalAge (StalAge_age) fits straight lines through three adjacent dates using weights based on the dating measurement errors (Scholz and Hoffmann, 2011). Age uncertainties are iteratively obtained through a Monte Carlo approach, but ensembles are not given in the output. StalAge was used to construct $13.1 \%$ of the original SISALv2 chronologies. The StalAge v1.0 R function has been updated to $\mathrm{R}$ version 3.4 , and the default outlier and reversal checks were enabled to run automatically. Hiatuses cannot be entered in StalAge v1.0, but the updated version incorporates a treatment of hiatuses based on the creation of temporary synthetic ages following Roesch and Rehfeld (2019). In contrast to other methods, mean ages instead of median ages are reported for StalAge, and the uncertainties are internally calculated and based on iterative fits considering dating uncertainties. StalAge was applied to $62 \%(n=320 / 512)$ of the SISAL records for which new chronologies were developed. 


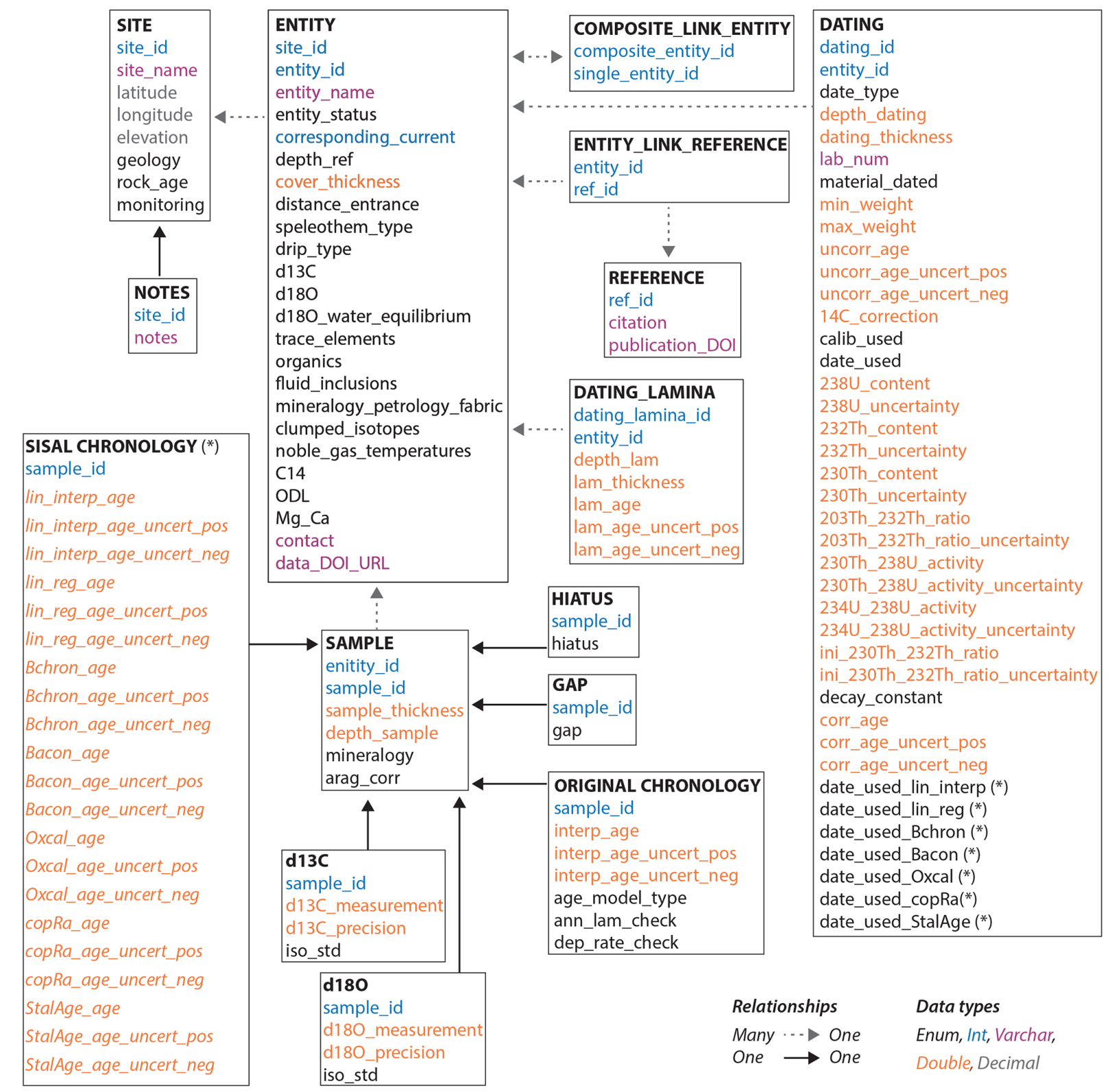

Figure 3. The structure of the SISAL database version 2. Fields and tables marked with $(*)$ refer to new information added to SISALv1b; see Tables 1 and 2 for details. The colours refer to the format of that field: Enum, Int, Varchar, Double or Decimal. More information on the list of predefined menus can be found in Atsawawaranunt et al. (2018a).

\subsection{Revised structure of the database}

The data are stored in a relational database (MySQL), which consists of 15 linked tables: site, entity, sample, dating, dating_lamina, gap, hiatus, original_chronology, d13C, d18O, entity_link_reference, references, composite_link_entity, notes and sisal_chronology. Figure 3 shows the relationships between these tables and the type of each field (e.g. numeric, text). The structure and contents of all tables except the new sisal_chronology table are described in detail in Atsawawaranunt et al. (2018a). Here, we focus on the new sisal_chronology table and on the changes that were made to other tables in order to accommodate this new table (see Sect. 2.3). Details of the fields in this new table are listed in Table 1.

Changes were also made to the dating table (dating) to accommodate information about whether a specific date was used to construct each of the age-depth models in the sisal_chronology table (Table 2). We followed the original authors' decision regarding the exclusion of dates (i.e. because of high uncertainties, age reversals or high detrital content). However, some dates used in the orig- 
Table 1. Details of the sisal_chronology table. All ages in SISAL are reported as years BP (before present), where present is 1950 CE.

\begin{tabular}{|c|c|c|c|}
\hline Field label & Description & Format & Constraints \\
\hline sample_id & $\begin{array}{l}\text { Refers to the unique identifier for the sample (as given in the sample } \\
\text { table) }\end{array}$ & Numeric & Positive integer \\
\hline lin_interp_age & $\begin{array}{l}\text { Age of the sample in years, calculated with linear interpolation between } \\
\text { dates }\end{array}$ & Numeric & None \\
\hline lin_interp_age_uncert_pos & $\begin{array}{l}\text { Positive 2-sigma uncertainty of the age of the sample in years, calcu- } \\
\text { lated with linear interpolation between dates }\end{array}$ & Numeric & Positive decimal \\
\hline lin_interp_age_uncert_neg & $\begin{array}{l}\text { Negative 2-sigma uncertainty of the age of the sample in years, calcu- } \\
\text { lated with linear interpolation between dates }\end{array}$ & Numeric & Positive decimal \\
\hline lin_reg_age & Age of the sample in years, calculated with linear regression & Numeric & None \\
\hline lin_reg_age_uncert_pos & $\begin{array}{l}\text { Positive 2-sigma uncertainty of the age of the sample in years, calcu- } \\
\text { lated with linear regression }\end{array}$ & Numeric & Positive decimal \\
\hline lin_reg_age_uncert_neg & $\begin{array}{l}\text { Negative 2-sigma uncertainty of the age of the sample in years, calcu- } \\
\text { lated with linear regression }\end{array}$ & Numeric & Positive decimal \\
\hline Bchron_age & Age of the sample in years, calculated with Bchron & Numeric & None \\
\hline Bchron_age_uncert_pos & $\begin{array}{l}\text { Positive 2-sigma uncertainty of the age of the sample in years, calcu- } \\
\text { lated with Bchron }\end{array}$ & Numeric & Positive decimal \\
\hline Bchron_age_uncert_neg & $\begin{array}{l}\text { Negative 2-sigma uncertainty of the age of the sample in years, calcu- } \\
\text { lated with Bchron }\end{array}$ & Numeric & Positive decimal \\
\hline Bacon_age & Age of the sample in years, calculated with Bacon & Numeric & None \\
\hline Bacon_age_uncert_pos & $\begin{array}{l}\text { Positive 2-sigma uncertainty of the age of the sample in years, calcu- } \\
\text { lated with Bacon }\end{array}$ & Numeric & Positive decimal \\
\hline Bacon_age_uncert_neg & $\begin{array}{l}\text { Negative 2-sigma uncertainty of the age of the sample in years, calcu- } \\
\text { lated with Bacon }\end{array}$ & Numeric & Positive decimal \\
\hline OxCal_age & Age of the sample in years, calculated with OxCal & Numeric & None \\
\hline OxCal_age_uncert_pos & $\begin{array}{l}\text { Positive 2-sigma uncertainty of the age of the sample in years, calcu- } \\
\text { lated with OxCal }\end{array}$ & Numeric & Positive decimal \\
\hline OxCal_age_uncert_neg & $\begin{array}{l}\text { Negative 2-sigma uncertainty of the age of the sample in years, calcu- } \\
\text { lated with OxCal }\end{array}$ & Numeric & Positive decimal \\
\hline copRa_age & Age of the sample in years, calculated with copRa & Numeric & None \\
\hline copRa_age_uncert_pos & $\begin{array}{l}\text { Positive 2-sigma uncertainty of the age of the sample in years, calcu- } \\
\text { lated with copRa }\end{array}$ & Numeric & Positive decimal \\
\hline copRa_age_uncert_neg & $\begin{array}{l}\text { Negative 2-sigma uncertainty of the age of the sample in years, calcu- } \\
\text { lated with copRa }\end{array}$ & Numeric & Positive decimal \\
\hline Stalage_age & Age of the sample in years, calculated with StalAge & Numeric & None \\
\hline Stalage_age_uncert_pos & $\begin{array}{l}\text { Positive 2-sigma uncertainty of the age of the sample in years, calcu- } \\
\text { lated with StalAge }\end{array}$ & Numeric & Positive decimal \\
\hline Stalage_age_uncert_neg & $\begin{array}{l}\text { Negative 2-sigma uncertainty of the age of the sample in years, calcu- } \\
\text { lated with StalAge }\end{array}$ & Numeric & Positive decimal \\
\hline
\end{tabular}


Table 2. Changes made to the dating table to accommodate the new age models. These changes are marked with (*) in Fig. 3.

\begin{tabular}{|c|c|c|c|c|}
\hline Action & Field label & Description & Format & Constraints \\
\hline Field added & date_used_lin_age & $\begin{array}{l}\text { Indication whether that date was used to } \\
\text { construct the linear age model }\end{array}$ & Text & Selected from predefined list: "yes", "no" \\
\hline Field added & date_used_lin_reg & $\begin{array}{l}\text { Indication whether that date was used to } \\
\text { construct the age model based on linear } \\
\text { regression }\end{array}$ & Text & Selected from predefined list: "yes", "no" \\
\hline Field added & date_used_Bchron & $\begin{array}{l}\text { Indication whether that date was used } \\
\text { to construct the age model based on } \\
\text { Bcrhon }\end{array}$ & Text & Selected from predefined list: "yes", "no" \\
\hline Field added & date_used_Bacon & $\begin{array}{l}\text { Indication whether that date was used to } \\
\text { construct the age model based on Bacon }\end{array}$ & Text & Selected from predefined list: "yes", "no" \\
\hline Field added & date_used_StalAge & $\begin{array}{l}\text { Indication whether that date was used to } \\
\text { construct the age model based on Sta- } \\
\text { lAge }\end{array}$ & Text & Selected from predefined list: "yes", "no" \\
\hline
\end{tabular}

inal age-depth model were not used in the SISALv2 chronologies to prevent unrealistic age-depth relationships (i.e. age inversions). Information on whether a particular date was used for the construction of specific type of age-depth model is provided in the dating table under columns labelled date_used_lin_interp, date_used_lin_reg, date_used_Bchron, date_used_Bacon, date_used_oxCal, date_used_copRa and date_used_StalAge (Table 2).

The dating and the sample tables were modified to accommodate the inclusion of new entities in the database. Specifically, the predefined option lists were expanded, options that had never been used were removed, and some typographical errors in the field names were corrected; these changes are listed in Table 3.

\section{Quality control}

\subsection{Quality control of individual speleothem records}

The quality control procedure for individual records newly incorporated in the SISALv2 database is based on the steps described in Atsawawaranunt et al. (2018a). We have updated the Python database scripts to provide a more thorough quality assessment of individual records. Additional checks of the dating table resulted in modifications in the 230Th_232Th, 230Th_238U,234U_238U, ini230Th_232Th, 238U_content, 230Th_content, 232Th_content and decay constant fields in the dating table for 60 entities. A summary of the fields that are both automatically and manually checked before uploading a record to the database is available in the Supplement.

Analyses of the data included in SISALv1 (Braun et al., 2019a; Burstyn et al., 2019; Deininger et al., 2019; Kaushal et al., 2018; Kern et al., 2019; Lechleitner et al., 2018; Oster et al., 2019; Zhang et al., 2019) and SISALv1b (Comas-Bru et al., 2019) revealed a number of errors in specific records that have now been corrected. These revisions include, for example, updates in mineralogies (sample.mineralogy), revised coordinates (site.latitude and/or site.longitude) and addition of missing information that was previously entered as "unknown". The fields affected and the number of records with modifications are listed in Table 4. All revisions are also documented in Comas-Bru et al. (2020a).

\subsection{Automation and quality control of the age-depth models in the SISAL chronology}

We used an automated approach to age-depth modelling in $\mathrm{R}$ because of the large number of records. Roesch and Rehfeld (2019) have described the basic workflow concept and tested it using all of the age-modelling approaches used here except OxCal. The basic workflow involves step-by-step inspection and formatting of the data for the different methods, and the use of predefined parameter choices is specific to each method. Each age-modelling method is called sequentially. An error message is recorded in the log file if a particular age-modelling method fails, and the algorithm then progresses to the next method. If output is produced for a par- 
Table 3. Changes made to tables other than the sisal_chronology since the publication of SISALv1 (Atsawawaranunt et al., 2018a, b).

\begin{tabular}{|c|c|c|c|c|c|}
\hline Table name & Action & Field label & Reason & Format & Constraints \\
\hline \multirow[t]{4}{*}{ Dating } & $\begin{array}{l}\text { Removed "sampling gap" } \\
\text { option }\end{array}$ & date_type & Option never used & Text & $\begin{array}{l}\text { Selected from pre- } \\
\text { defined list }\end{array}$ \\
\hline & $\begin{array}{l}\text { The "others" option } \\
\text { changed to "other" }\end{array}$ & decay_constant & Correction of typo & Text & $\begin{array}{l}\text { Selected from pre- } \\
\text { defined list }\end{array}$ \\
\hline & Added "other" option & calib_used & $\begin{array}{l}\text { Option added to accommodate } \\
\text { new entities }\end{array}$ & Text & $\begin{array}{l}\text { Selected from pre- } \\
\text { defined list }\end{array}$ \\
\hline & Added "other" option & date_type & $\begin{array}{l}\text { Option added to accommodate } \\
\text { new entities }\end{array}$ & Text & $\begin{array}{l}\text { Selected from pre- } \\
\text { defined list }\end{array}$ \\
\hline \multirow[t]{2}{*}{ Sample } & Added "other" option & original_chronology & $\begin{array}{l}\text { Option added to accommodate } \\
\text { new entities }\end{array}$ & Text & $\begin{array}{l}\text { Selected from pre- } \\
\text { defined list }\end{array}$ \\
\hline & Added "other" option & ann_lam_check & $\begin{array}{l}\text { Option added to accommodate } \\
\text { new entities }\end{array}$ & Text & $\begin{array}{l}\text { Selected from pre- } \\
\text { defined list }\end{array}$ \\
\hline
\end{tabular}

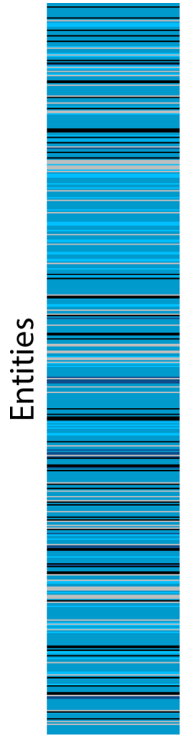

Lin. interp. 403

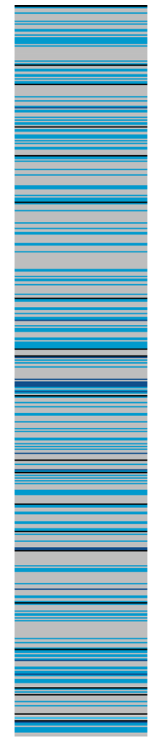

Lin. reg 182

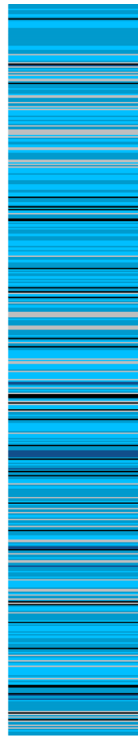

Bchron 420

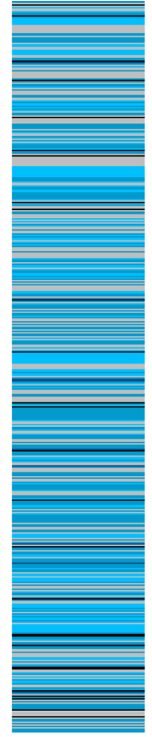

Bacon 328

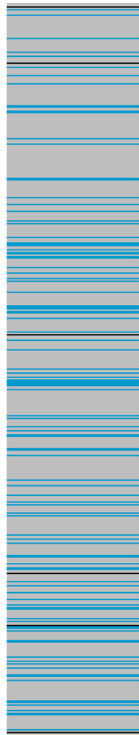

OxCal 106

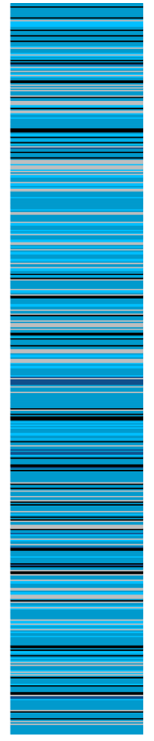

copRa 381

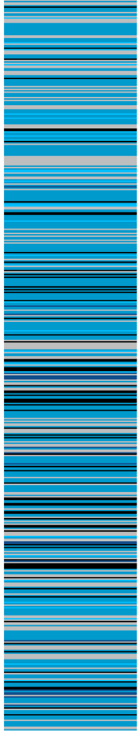

StalAge

318

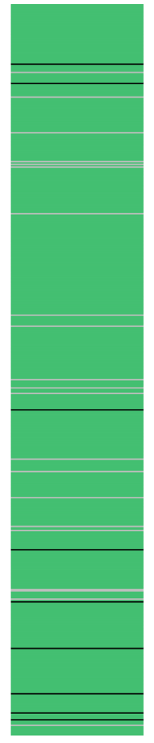

Success

$503 / 533$

Age model evaluation

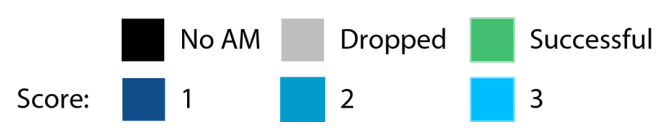

Figure 4. Visual summary of quality control of the automated SISAL chronology construction. The evaluation of the age-depth models for each method ( $x$ axis) is given for each entity ( $y$ axis) that was considered for the construction $(n=533)$. Black lines mark age-depth models that could not be computed. Age-depth models dropped in the automated or expert evaluation are marked by grey lines. Age-depth models retained in SISALv2 are scored from 1 (only one criterion satisfied) to 3 (all criteria satisfied) in shades of blue. For 503 records alternative age-depth models with uncertainties are provided (green lines) in the "success" column.

ticular age-modelling method, these age models are checked for monotonicity. Finally, the output standardization routine writes out, for each entity and age-modelling approach, the median age model, the ensembles (if applicable) and information of which hiatuses and dates were used in the construction of the age models. These outputs are then added to the sisal_chronology table (Table 2). All functions are avail- able at https://github.com/paleovar/SISAL.AM (last access: 23 July 2020).

The general approach for the OxCal age models was similar, and step-by-step details and scripts are provided at https://doi.org/10.5281/zenodo.3586280 (AmirnezhadMozhdehi and Comas-Bru, 2019). The quality control parameters obtained from OxCal were compared with the rec- 
Table 4. Summary of the modifications applied to records already in version 1 (Atsawawaranunt et al., 2018b) and version 1b (Atsawawaranunt et al., 2019) of the SISAL database. Mistakes in previous versions of the database were identified as outlined in the Supplement and through analysing the data for the SISAL publications.

\begin{tabular}{lrr}
\hline Modification & V1 to v1b & V1b to v2 \\
\hline Site table & & \\
\hline Number of new sites & 37 & 82 \\
Sites with new entities & 11 & 32 \\
Sites with altered site.site_name altered & 3 & 15 \\
Sites with changes in site.latitude & 4 & 29 \\
Sites with changes in site.longitude & 6 & 32 \\
Sites with changes in site.elevation & 13 & 11 \\
Sites with site.geology updated & 7 & 6 \\
Sites with site.rock_age info updated & 3 & 8 \\
Sites with site.monitoring info updated & 0 & 13 \\
\hline
\end{tabular}

Entity table

$\begin{array}{ll}\text { Number of new entities } & 74\end{array}$

How many entities were added to pre-existing sites?

Entities with revised entity_name

Entities with updated entity.entity_status

Entities with altered entity.corresponding current

Entities with altered entity.depth_ref?

Entities with altered entity.cover_thickness

Entities with altered entity.distance_entrance

Entities with revised entity. speleothem_type

Entities with revised entity.drip_type

Entities with altered entity.d13C

Entities with altered entity.d180

Entities with altered entity.d180_water_equilibrium

Entities with altered entity.trace_elements

Entities with altered entity.organics

Entities with altered entity.fluid_inclusions

Entities with altered entity.mineralogy_petrology_fabric

Entities with altered entity.clumped_isotopes

Entities with altered entity.noble_gas_temperatures

Entities with altered entity.C14

Entities with altered entity.ODL

Entities with altered entity.Mg_Ca

Entities with altered entity.contact (mostly correction of typos)

Entities with altered entity.Data_DOI_URL (revision mostly to permanent links)

$\begin{array}{rr}74 & 236 \\ 17 & 84 \\ 2 & 25 \\ 1 & 10 \\ 0 & 11 \\ 0 & 1 \\ 1 & 3 \\ 0 & 3 \\ 14 & 4 \\ 10 & 2 \\ 1 & 0 \\ 1 & 0 \\ 4 & 6 \\ 1 & 2 \\ 1 & 2 \\ 1 & 3 \\ 1 & 2 \\ 1 & 3 \\ 1 & 2 \\ 1 & 2 \\ 1 & 2 \\ 1 & 2 \\ 7 & 32 \\ 134 & 14\end{array}$

Dating table

Entities with changes in the dating table

Addition of "Event: hiatus" to an entity

How many hiatuses had their depth changed?

Entities with the depths of "Event: start/end of laminations" changed

Entities with altered dating.date_type

Entities with altered dating.depth_dating

Entities with altered dating.dating_thickness

Entities with altered dating.material_dated

70

Entities with altered dating.min_weight

Entities with altered dating.max_weight

Entities with altered dating.uncorr_age

Entities with altered dating.uncorr_age_uncert_pos

Entities with altered dating.uncorr_age_uncert_neg

Entities with altered dating.14C_correction

$17 \quad 36$


Table 4. Continued.

\begin{tabular}{lrr}
\hline Modification & V1 to v1b & V1b to v2 \\
\hline Entities with altered dating.calib_used & 13 & 32 \\
Entities with altered dating.date_used & 4 & 51 \\
Entities with altered dating.238U_content & 11 & 47 \\
Entities with altered dating.238U_uncertainty & 16 & 29 \\
Entities with altered dating.232Th_content & 15 & 46 \\
Entities with altered dating.232Th_uncertainty & 14 & 50 \\
Entities with altered dating.230Th_content & 11 & 40 \\
Entities with altered dating.230Th_uncertainty & 15 & 38 \\
Entities with altered dating.230Th_232Th_ratio & 5 & 60 \\
Entities with altered dating.230Th_232Th_ratio_uncertainty & 14 & 49 \\
Entities with altered dating.230Th_238U_activity & 19 & 40 \\
Entities with altered dating.230Th_238U_activity_uncertainty & 17 & 49 \\
Entities with altered dating.234U_238U_activity & 12 & 40 \\
Entities with altered dating.234U_238U_activity_uncertainty & 11 & 40 \\
Entities with altered dating.ini_230Th_232Th_ratio & 15 & 41 \\
Entities with altered dating.ini_230Th_232Th_ratio_uncertainty & 8 & 49 \\
Entities with altered dating.decay_constant & 17 & 55 \\
Entities with altered dating.corr_age & 17 & 36 \\
Entities with altered dating.corr_age_uncert_pos & 13 & 47 \\
Entities with altered dating.corr_age_uncert_neg & 9 & 52 \\
\hline
\end{tabular}

Sample table

\begin{tabular}{lrr}
\hline Altered sample.depth_sample & 0 & 15 \\
Altered sample.mineralogy & 0 & 20 \\
Altered sample.arag_corr & 11 & 20 \\
How many entities had their d18O time series altered (i.e. changes in depth & 13 & 96 \\
and/or isotope values as in duplicates)? & 8 & 64 \\
How many entities had their d13C time series altered (i.e. changes in depth & & \\
and/or isotope values as in duplicates)? & 1 & 42 \\
\hline Original chronology & 0 & 14 \\
\hline Entities with altered original_chronology.interp_age & 0 & 14 \\
Entities with altered original_chronology.interp_age_uncert_pos & & \\
Entities with altered original_chronology.interp_age_uncert_neg & 6 & 16 \\
\hline References & 2 & 16 \\
\hline How many entities had their references changed (changes/additions/removals)? & & \\
How many citations have a different pub_DOI? & 7 & 5 \\
\hline Notes & 32 & 68 \\
\hline Sites with notes removed & 21 & 33 \\
Sites with notes added & & \\
Sites with notes modified & & \\
\hline
\end{tabular}

ommended values of the agreement index $(A)>60 \%$ and convergence $(C)>95 \%$ in accordance with the guidelines in Bronk Ramsey (2008), both for the overall model and for at least $90 \%$ of the individual dates. OxCal age-depth models failing to meet these criteria were not included in the sisal_chronology table (Table 2).

An overview of the evaluation results for the age-depth models constructed in automated mode is given in Fig. 4. Three nested criteria are used to evaluate them. Firstly, chronologies with reversals (Check 1) are automatically rejected (score -1). Secondly, the final chronology should flexibly follow clear growth rate changes (Check 2) such that $70 \%$ of the dates are encompassed in the final age-depth model within 4-sigma uncertainty (score +1$)$. Thirdly, temporal uncertainties are expected to increase between dates and near hiatuses (Check 3). This criterion is met in the automated screening $($ score +1$)$ if the interquartile range (IQR) is higher between dates or at hiatuses than at dates. Only 
Table 5. Information on new speleothem records (entities) added to the SISAL_v2 database from SISALv1b (Comas-Bru et al., 2019). There may be multiple entities from a single cave, here identified as the site. Latitude (Lat) and Longitude (Long) are given in decimal degrees north and east, respectively.

\begin{tabular}{|c|c|c|c|c|c|c|c|}
\hline Site ID & Site name & Lat $(\mathrm{N})$ & Long $(\mathrm{E})$ & Region & Entity ID & Entity name & Reference \\
\hline \multirow[t]{4}{*}{2} & Kesang cave & 42.87 & 81.75 & China & 620 & CNKS-2 & Cai et al. (2017) \\
\hline & & & & & 621 & CNKS-3 & Cai et al. (2017) \\
\hline & & & & & 622 & CNKS-7 & Cai et al. (2017) \\
\hline & & & & & 623 & CNKS-9 & Cai et al. (2017) \\
\hline \multirow[t]{3}{*}{6} & Hulu cave & 32.5 & 119.17 & China & 617 & MSP & Cheng et al. (2006) \\
\hline & & & & & 618 & MSX & Cheng et al. (2006) \\
\hline & & & & & 619 & MSH & Cheng et al. (2006) \\
\hline \multirow[t]{3}{*}{12} & Mawmluh cave & 25.2622 & 91.8817 & India & 476 & ML.1 & Kathayat et al. (2018) \\
\hline & & & & & 477 & ML.2 & Kathayat et al. (2018) \\
\hline & & & & & 495 & KM-1 & Huguet et al. (2018) \\
\hline \multirow[t]{4}{*}{13} & Ball Gown cave & -17.03 & 125 & Australia & 633 & BGC-5 & Denniston et al. (2013b, 2017) \\
\hline & & & & & 634 & BGC-10 & Denniston et al. (2013b, 2017) \\
\hline & & & & & 635 & BGC-11_2017 & Denniston et al. (2013b, 2017) \\
\hline & & & & & 636 & BGC-16 & Denniston et al. (2013b, 2017) \\
\hline \multirow[t]{2}{*}{14} & Lehman caves & 39.01 & -114.22 & United States & 641 & CDR3 & Steponaitis et al. (2015) \\
\hline & & & & & 642 & WR11 & Steponaitis et al. (2015) \\
\hline \multirow[t]{2}{*}{15} & Baschg cave & 47.2501 & 9.6667 & Austria & 643 & BA-5 & Moseley et al. (2020) \\
\hline & & & & & 644 & BA-7 & Moseley et al. (2020) \\
\hline \multirow[t]{3}{*}{23} & Lapa grande cave & -14.37 & -44.28 & Brazil & 614 & LG12B & Stríkis et al. (2018) \\
\hline & & & & & 615 & LG10 & Stríkis et al. (2018) \\
\hline & & & & & 616 & LG25 & Stríkis et al. (2018) \\
\hline \multirow[t]{5}{*}{24} & Lapa sem fim cave & -16.1503 & -44.6281 & Brazil & 603 & LSF15 & Stríkis et al. (2018) \\
\hline & & & & & 604 & LSF3_2018 & Stríkis et al. (2018) \\
\hline & & & & & 605 & LSF13 & Stríkis et al. (2018) \\
\hline & & & & & 606 & LSF11 & Stríkis et al. (2018) \\
\hline & & & & & 607 & LSF9 & Stríkis et al. (2018) \\
\hline 27 & Tamboril cave & -16 & -47 & Brazil & 594 & TM6 & Ward et al. (2019) \\
\hline 39 & Dongge cave & 25.2833 & 108.0833 & China & 475 & DA_2009 & Cheng et al. (2009) \\
\hline \multirow[t]{3}{*}{54} & Sahiya cave & 30.6 & 77.8667 & India & 478 & SAH-2 & Kathayat et al. (2017) \\
\hline & & & & & 479 & SAH-3 & Kathayat et al. (2017) \\
\hline & & & & & 480 & SAH-6 & Kathayat et al. (2017) \\
\hline \multirow[t]{2}{*}{65} & Whiterock cave & 4.15 & 114.86 & $\begin{array}{l}\text { Malaysia } \\
\text { (Borneo) }\end{array}$ & 685 & WR12-01 & Carolin et al. (2016) \\
\hline & & & & & 686 & WR12-12 & Carolin et al. (2016) \\
\hline 72 & Ascunsa cave & 45 & 22.6 & Romania & 582 & POM1 & Staubwasser et al. (2018) \\
\hline 82 & Hollywood cave & -41.95 & 171.47 & New Zealand & 673 & HW-1 & Williams et al. (2005) \\
\hline \multirow[t]{2}{*}{86} & Modric cave & 44.2568 & 15.5372 & Croatia & 631 & MOD-27 & Rudzka-Phillips et al. (2013) \\
\hline & & & & & 632 & MOD-21 & Rudzka et al. (2012) \\
\hline 105 & Schneckenloch cave & 47.4333 & 9.8667 & Austria & 663 & SCH-6 & Moseley et al. (2020) \\
\hline \multirow[t]{2}{*}{113} & Paixao cave & -12.6182 & -41.0184 & Brazil & 611 & PX5 & Strikis et al. (2015) \\
\hline & & & & & 612 & PX7_2018 & Stríkis et al. (2018) \\
\hline 115 & Hölloch im Mahdtal & 47.3781 & 10.1506 & Germany & 664 & HOL-19 & Moseley et al. (2020) \\
\hline 117 & Bunker cave & 51.3675 & 7.6647 & Germany & 596 & Bu2_2018 & Weber et al. (2018) \\
\hline \multirow[t]{3}{*}{128} & Buckeye creek & 37.98 & -80.4 & United States & 681 & BCC-9 & Cheng et al. (2019) \\
\hline & & & & & 682 & BCC-10_2019 & Cheng et al. (2019) \\
\hline & & & & & 683 & BCC-30 & Cheng et al. (2019) \\
\hline \multirow[t]{2}{*}{135} & Grotte de Piste & 33.95 & -4.246 & Morocco & 464 & GP5 & Ait Brahim et al. (2018) \\
\hline & & & & & 591 & GP2 & Ait Brahim et al. (2018) \\
\hline 138 & Moomi cave & 12.55 & 54.2 & $\begin{array}{l}\text { Yemen (Soco- } \\
\text { tra) }\end{array}$ & 481 & M1-2 & $\begin{array}{l}\text { Mangini, Cheng et al. } \\
\text { (unpublished data); } \\
\text { Burns et al. (2003, 2004) }\end{array}$ \\
\hline
\end{tabular}


Table 5. Continued.

\begin{tabular}{|c|c|c|c|c|c|c|c|}
\hline Site ID & Site name & Lat $(\mathrm{N})$ & Long (E) & Region & Entity ID & Entity name & Reference \\
\hline 140 & Sanbao cave & 31.667 & 110.4333 & China & $\begin{array}{l}482 \\
483 \\
484 \\
485 \\
486 \\
487 \\
488 \\
489 \\
490 \\
491 \\
492 \\
493 \\
494\end{array}$ & $\begin{array}{l}\text { SB3 } \\
\text { SB-10_2008 } \\
\text { SB11 } \\
\text { SB22 } \\
\text { SB23 } \\
\text { SB24 } \\
\text { SB25-1 } \\
\text { SB25-2 } \\
\text { SB-26_2008 } \\
\text { SB34 } \\
\text { SB41 } \\
\text { SB42 } \\
\text { TF }\end{array}$ & $\begin{array}{l}\text { Wang et al. (2008) } \\
\text { Wang et al. (2008) } \\
\text { Wang et al. (2008) } \\
\text { Wang et al. (2008) } \\
\text { Wang et al. (2008) } \\
\text { Wang et al. (2008) } \\
\text { Wang et al. (2008) } \\
\text { Wang et al. (2008) } \\
\text { Wang et al. (2008) } \\
\text { Wang et al. (2008) } \\
\text { Wang et al. (2008) } \\
\text { Wang et al. (2008) } \\
\text { Wang et al. (2008) }\end{array}$ \\
\hline 141 & Sofular cave & 41.4167 & 31.9333 & Turkey & $\begin{array}{l}687 \\
688 \\
689\end{array}$ & $\begin{array}{l}\text { SO-2 } \\
\\
\text { SO-4 } \\
\text { SO-6 } \\
\text { SO-14B }\end{array}$ & $\begin{array}{l}\text { Badertscher et al. (2011) } \\
\text { Fleitmann et al. (2009); } \\
\text { Göktürk et al. (2011) } \\
\text { Badertscher et al. (2011) } \\
\text { Badertscher et al. (2011) } \\
\text { Badertscher et al. (2011) }\end{array}$ \\
\hline 145 & Antro del Corchia & 43.9833 & 10.2167 & Italy & $\begin{array}{l}665 \\
666 \\
667 \\
668 \\
669 \\
670\end{array}$ & $\begin{array}{l}\text { CC-1_2018 } \\
\text { CC-5_2018 } \\
\text { CC-7_2018 } \\
\text { CC-28_2018 } \\
\text { CC_stack } \\
\text { CC27 }\end{array}$ & $\begin{array}{l}\text { Tzedakis et al. (2018) } \\
\text { Tzedakis et al. (2018) } \\
\text { Tzedakis et al. (2018) } \\
\text { Tzedakis et al. (2018) } \\
\text { Tzedakis et al. (2018) } \\
\text { Isola et al. (2019) }\end{array}$ \\
\hline 155 & KNI-51 & -15.3 & 128.62 & Australia & $\begin{array}{l}637 \\
638\end{array}$ & $\begin{array}{l}\text { KNI-51-1 } \\
\text { KNI-51-8 }\end{array}$ & $\begin{array}{l}\text { Denniston et al. (2017) } \\
\text { Denniston et al. (2017) }\end{array}$ \\
\hline 160 & Soreq cave & 31.7558 & 35.0226 & Israel & 690 & Soreq-composite 185 & Bar-Matthews et al. (2003) \\
\hline 165 & Ruakuri cave & -36.27 & 175.08 & New Zealand & $\begin{array}{l}674 \\
675 \\
676 \\
677 \\
678\end{array}$ & $\begin{array}{l}\text { RK-A } \\
\text { RK-B } \\
\text { RK05-1 } \\
\text { RK05-3 } \\
\text { RK05-4 }\end{array}$ & $\begin{array}{l}\text { Williams et al. (2010) } \\
\text { Williams et al. (2010) } \\
\text { Whittaker (2008) } \\
\text { Whittaker (2008) } \\
\text { Whittaker (2008) }\end{array}$ \\
\hline 177 & Santo Tomas cave & 22.55 & -83.84 & Cuba & $\begin{array}{l}608 \\
609 \\
610\end{array}$ & $\begin{array}{l}\text { CM_2019 } \\
\text { CMa } \\
\text { CMb }\end{array}$ & $\begin{array}{l}\text { Warken et al. (2019) } \\
\text { Warken et al. (2019) } \\
\text { Warken et al. (2019) }\end{array}$ \\
\hline 179 & Closani cave & 45.10 & 22.8 & Romania & 390 & $\mathrm{C} 09-2$ & Warken et al. (2018) \\
\hline 182 & Kotumsar cave & 19 & 82 & India & 590 & KOT-I & Band et al. (2018) \\
\hline 192 & El Condor cave & -5.93 & -77.3 & Peru & $\begin{array}{l}592 \\
593\end{array}$ & $\begin{array}{l}\text { ELC-A } \\
\text { ELC-B }\end{array}$ & $\begin{array}{l}\text { Cheng et al. (2013) } \\
\text { Cheng et al. (2013) }\end{array}$ \\
\hline 198 & Lianhua cave, Hunan & 29.48 & 109.5333 & China & 496 & LH-2 & Zhang et al. (2013) \\
\hline 213 & Tausoare cave & 47.4333 & 24.5167 & Romania & 457 & 1152 & Staubwasser et al. (2018) \\
\hline 214 & Cave C126 & -22.1 & 113.9 & Australia & $\begin{array}{l}458 \\
459\end{array}$ & $\begin{array}{l}\text { C126-117 } \\
\text { C126-118 }\end{array}$ & $\begin{array}{l}\text { Denniston et al. (2013a) } \\
\text { Denniston et al. (2013a) }\end{array}$ \\
\hline 215 & Chaara cave & 33.9558 & -4.2461 & Morocco & $\begin{array}{l}460 \\
588 \\
589\end{array}$ & $\begin{array}{l}\text { Cha2_2018 } \\
\text { Cha2_2019 } \\
\text { Cha1 }\end{array}$ & $\begin{array}{l}\text { Ait Brahim et al. (2018) } \\
\text { Ait Brahim et al. (2019) } \\
\text { Ait Brahim et al. (2019) }\end{array}$ \\
\hline 216 & Dark cave & 27.2 & 106.1667 & China & $\begin{array}{l}461 \\
462\end{array}$ & $\begin{array}{l}\text { D1 } \\
\text { D2 }\end{array}$ & $\begin{array}{l}\text { Jiang et al. (2013) } \\
\text { Jiang et al. (2013) }\end{array}$ \\
\hline 217 & E'mei cave & 29.5 & 115.5 & China & 463 & EM1 & Zhang et al. (2018b) \\
\hline 218 & Nuanhe cave & 41.3333 & 124.9167 & China & $\begin{array}{l}465 \\
466\end{array}$ & $\begin{array}{l}\text { NH6 } \\
\text { NH33 }\end{array}$ & $\begin{array}{l}\text { Wu et al. (2012) } \\
\text { Wu et al. (2012) }\end{array}$ \\
\hline
\end{tabular}


Table 5. Continued.

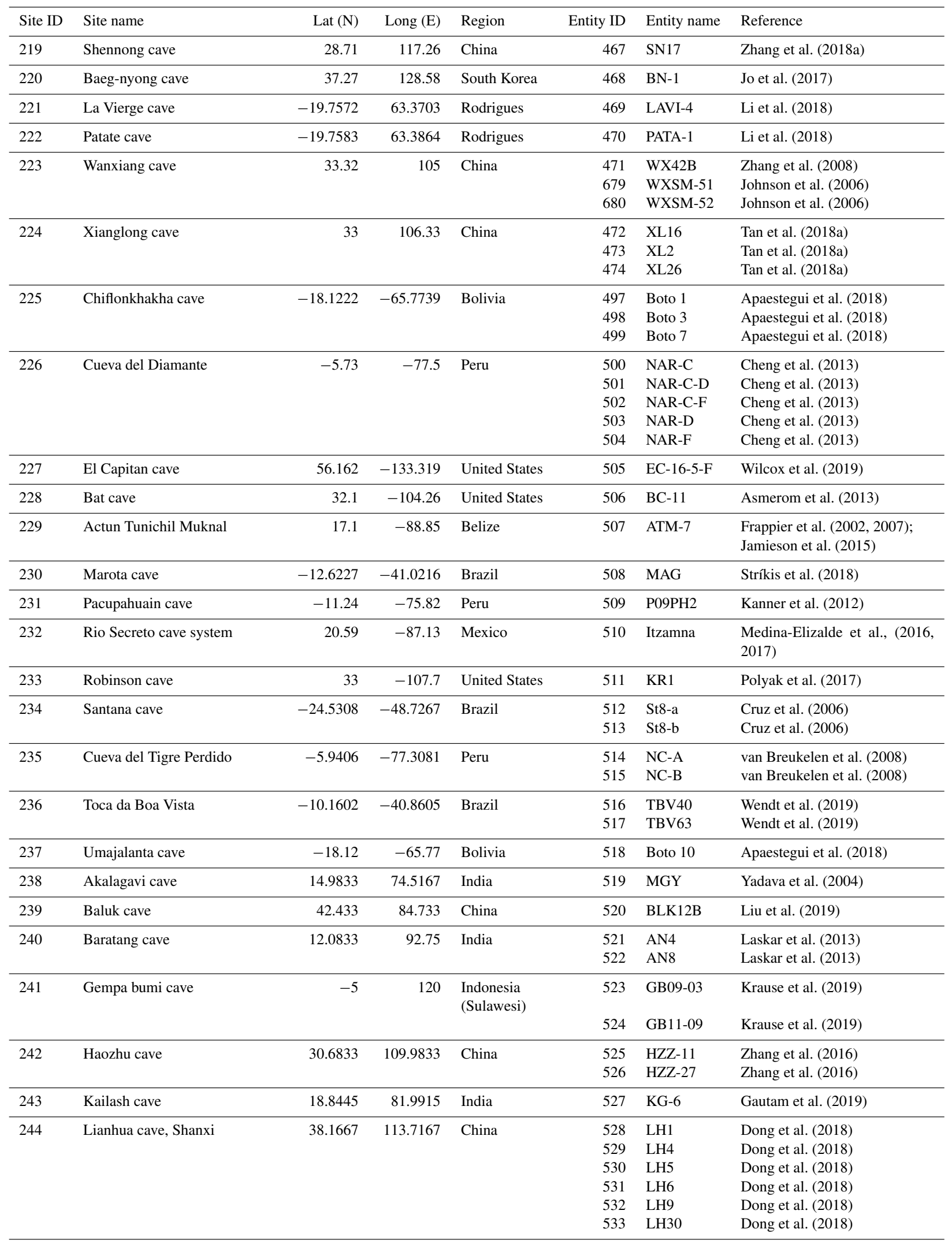


Table 5. Continued.

\begin{tabular}{|c|c|c|c|c|c|c|c|}
\hline Site ID & Site name & Lat $(\mathrm{N})$ & Long (E) & Region & Entity ID & Entity name & Reference \\
\hline 245 & Nakarallu cave & 14.52 & 77.99 & India & 534 & NK-1305 & Sinha et al. (2018) \\
\hline 246 & Palawan cave & 10.2 & 118.9 & $\begin{array}{l}\text { Malaysia } \\
\text { (northern } \\
\text { Borneo) }\end{array}$ & 535 & SR02 & Partin et al. (2015) \\
\hline 247 & Shalaii cave & 35.1469 & 45.2958 & Iraq & $\begin{array}{l}536 \\
537\end{array}$ & $\begin{array}{l}\text { SHC-01 } \\
\text { SHC-02 }\end{array}$ & $\begin{array}{l}\text { Marsh et al. (2018); } \\
\text { Amin Al-Manmi et al. (2019) } \\
\text { Marsh et al. (2018); } \\
\text { Amin Al-Manmi et al. (2019) }\end{array}$ \\
\hline 248 & Shenqi cave & 28.333 & 103.1 & China & $\begin{array}{l}538 \\
539\end{array}$ & $\begin{array}{l}\text { SQ1 } \\
\text { SQ7 }\end{array}$ & $\begin{array}{l}\text { Tan et al. (2018b) } \\
\text { Tan et al. (2018b) }\end{array}$ \\
\hline 249 & Shigao cave & 28.183 & 107.167 & China & $\begin{array}{l}540 \\
541\end{array}$ & $\begin{array}{l}\text { SG1 } \\
\text { SG2 }\end{array}$ & $\begin{array}{l}\text { Jiang et al. (2012) } \\
\text { Jiang et al. (2012) }\end{array}$ \\
\hline 250 & Wuya cave & 33.82 & 105.43 & China & $\begin{array}{l}542 \\
543\end{array}$ & $\begin{array}{l}\text { WY27 } \\
\text { WY33 }\end{array}$ & $\begin{array}{l}\text { Tan et al. (2015) } \\
\text { Tan et al. (2015) }\end{array}$ \\
\hline 251 & Zhenzhu cave & 38.25 & 113.7 & China & 544 & $\mathrm{ZZ12}$ & Yin et al. (2017) \\
\hline 252 & Andriamaniloke & -24.051 & 43.7569 & Madagascar & 545 & $\mathrm{AD} 4$ & Scroxton et al. (2019) \\
\hline 253 & Hoq cave & 12.5866 & 54.3543 & $\begin{array}{l}\text { Yemen } \\
\text { (Socotra) }\end{array}$ & $\begin{array}{l}546 \\
547 \\
548\end{array}$ & $\begin{array}{l}\text { Hq-1 } \\
\text { STM1 } \\
\text { STM6 }\end{array}$ & $\begin{array}{l}\text { Van Rampelbergh et al. (2013) } \\
\text { Van Rampelbergh et al. (2013) } \\
\text { Van Rampelbergh et al. (2013) }\end{array}$ \\
\hline 254 & PP29 & -34.2078 & 22.0876 & South Africa & $\begin{array}{l}549 \\
550 \\
551 \\
552 \\
553 \\
554 \\
555 \\
556\end{array}$ & $\begin{array}{l}46745 \\
46746-\mathrm{a} \\
46747 \\
138862.1 \\
138862.2 \mathrm{a} \\
142828 \\
46746-\mathrm{b} \\
138862.2 \mathrm{~b}\end{array}$ & $\begin{array}{l}\text { Braun et al. (2019b) } \\
\text { Braun et al. (2019b) } \\
\text { Braun et al. (2019b) } \\
\text { Braun et al. (2019b) } \\
\text { Braun et al. (2019b) } \\
\text { Braun et al. (2019b) } \\
\text { Braun et al. (2019b) } \\
\text { Braun et al. (2019b) }\end{array}$ \\
\hline 255 & Mitoho & -24.0477 & 43.7533 & Madagascar & 557 & MT1 & Scroxton et al. (2019) \\
\hline 256 & Lithophagus cave & 46.828 & 22.6 & Romania & 558 & LFG-2 & Lauritzen and Onac (1999) \\
\hline 257 & Akcakale cave & 40.4498 & 39.5365 & Turkey & 559 & $2 p$ & Jex et al. $(2010,2011,2013)$ \\
\hline 258 & B7 cave & 49 & 7 & Germany & 560 & STAL-B7-7 & Niggemann et al. (2003b) \\
\hline 259 & Cobre cave & 42.98 & -4.37 & Spain & 561 & PA-8 & $\begin{array}{l}\text { Osete et al. (2012); } \\
\text { Rossi et al. (2014) }\end{array}$ \\
\hline 260 & Crovassa Azzurra & 39.28 & 8.48 & Italy & 562 & CA & Columbu et al. (2019) \\
\hline 261 & El Soplao cave & 43.2962 & -4.3937 & Spain & 563 & SIR-1 & Rossi et al. (2018) \\
\hline 262 & Bleßberg cave & 50.4244 & 11.0203 & Germany & $\begin{array}{l}564 \\
565\end{array}$ & $\begin{array}{l}\text { BB-1 } \\
\text { BB-3 }\end{array}$ & $\begin{array}{l}\text { Breitenbach et al. (2019) } \\
\text { Breitenbach et al. (2019) }\end{array}$ \\
\hline 263 & Orlova Chuka cave & 43.5937 & 25.9597 & Bulgaria & 566 & ocz-6 & Pawlak et al. (2019) \\
\hline 264 & Strašna peć cave & 44.0049 & 15.0388 & Croatia & $\begin{array}{l}567 \\
568\end{array}$ & $\begin{array}{l}\text { SPD-1 } \\
\text { SPD-2 }\end{array}$ & $\begin{array}{l}\text { Lončar et al. (2019) } \\
\text { Lončar et al. (2019) }\end{array}$ \\
\hline 265 & Coves de Campanet & 39.7937 & 2.9683 & Spain & 569 & CAM-1 & Dumitru et al. (2018) \\
\hline 266 & Cueva Victoria & 37.6322 & -0.8215 & Spain & 570 & Vic-III-4 & Budsky et al. (2019) \\
\hline 267 & Gruta do Casal da Lebre & 39.3 & -9.2667 & Portugal & 571 & GCL6 & Denniston et al. (2018) \\
\hline 268 & Pere Noel cave & 50 & 5.2 & Belgium & 572 & PN-95-5 & Verheyden et al. $(2000,2014)$ \\
\hline 269 & Gejkar cave & 35.8 & 45.1645 & Iraq & 573 & Gej-1 & Flohr et al. (2017) \\
\hline 270 & Gol-E-Zard cave & 35.84 & 52 & Iran & 574 & GZ14-1 & Carolin et al. (2019) \\
\hline 271 & Jersey cave & -35.72 & 148.49 & Australia & 575 & YB-F1 & Webb et al. (2014) \\
\hline 272 & Metro cave & -41.93 & 171.47 & New Zealand & 576 & M-1 & Logan (2011) \\
\hline 273 & Crystal cave & 36.59 & -118.82 & United States & 577 & CRC-3 & McCabe-Glynn et al. (2013) \\
\hline
\end{tabular}


Table 5. Continued.

\begin{tabular}{|c|c|c|c|c|c|c|c|}
\hline Site ID & Site name & Lat $(\mathrm{N})$ & Long (E) & Region & Entity ID & Entity name & Reference \\
\hline 274 & Terciopelo cave & 10.17 & -85.33 & Costa Rica & $\begin{array}{l}578 \\
579 \\
580 \\
581\end{array}$ & $\begin{array}{l}\text { CT-1 } \\
\text { CT-5 } \\
\text { CT-6 } \\
\text { CT-7 }\end{array}$ & $\begin{array}{l}\text { Lachniet et al. (2009) } \\
\text { Lachniet et al. (2009) } \\
\text { Lachniet et al. (2009) } \\
\text { Lachniet et al. (2009) }\end{array}$ \\
\hline 275 & Buraca Gloriosa & 39.5333 & -8.7833 & Portugal & $\begin{array}{l}583 \\
584 \\
585 \\
586 \\
587\end{array}$ & $\begin{array}{l}\text { BG41 } \\
\text { BG66 } \\
\text { BG67 } \\
\text { BG611 } \\
\text { BG6LR }\end{array}$ & $\begin{array}{l}\text { Denniston et al. (2018) } \\
\text { Denniston et al. (2018) } \\
\text { Denniston et al. (2018) } \\
\text { Denniston et al. (2018) } \\
\text { Denniston et al. (2018) }\end{array}$ \\
\hline 276 & Béke cave & 48.4833 & 20.5167 & Hungary & 595 & BNT-2 & $\begin{array}{l}\text { Demény et al. (2019) } \\
\text { Czuppon et al. (2018) }\end{array}$ \\
\hline 277 & Huagapo cave & -11.27 & -75.79 & Peru & $\begin{array}{l}597 \\
598 \\
599 \\
600 \\
601 \\
602\end{array}$ & $\begin{array}{l}\text { P00-H2 } \\
\text { P00-H1 } \\
\text { P09-H1b } \\
\text { P10-H5 } \\
\text { P10-H2 } \\
\text { PeruMIS6Composite }\end{array}$ & $\begin{array}{l}\text { Kanner et al. (2013) } \\
\text { Kanner et al. (2013) } \\
\text { Burns et al. (2019) } \\
\text { Burns et al. (2019) } \\
\text { Burns et al. (2019) } \\
\text { Burns et al. (2019) }\end{array}$ \\
\hline 278 & Pink Panther cave & 32 & -105.2 & United States & 613 & PP1 & Asmerom et al. (2007) \\
\hline 279 & Staircase cave & -34.2071 & 22.0899 & South Africa & $\begin{array}{l}624 \\
625 \\
626 \\
627 \\
628 \\
629 \\
630\end{array}$ & $\begin{array}{l}46322 \\
46330-\mathrm{a} \\
46861 \\
50100 \\
142819 \\
142820 \\
46330-\mathrm{b}\end{array}$ & $\begin{array}{l}\text { Braun et al. (2019b) } \\
\text { Braun et al. (2019b) } \\
\text { Braun et al. (2019b) } \\
\text { Braun et al. (2019b) } \\
\text { Braun et al. (2019b) } \\
\text { Braun et al. (2019b) } \\
\text { Braun et al. (2019b) }\end{array}$ \\
\hline 280 & Atta cave & 51.1 & 7.9 & Germany & 639 & AH-1 & Niggemann et al. (2003a) \\
\hline 281 & Venado cave & 10.55 & -84.77 & Costa Rica & 640 & $\mathrm{~V} 1$ & Lachniet et al. (2004) \\
\hline 282 & Wadi Sannur cave & 28.6167 & 31.2833 & Eqypt & 691 & WS-5d & El-Shenawy et al. (2018) \\
\hline 283 & Babylon cave & -41.95 & 171.47 & New Zealand & $\begin{array}{l}645 \\
646 \\
647\end{array}$ & $\begin{array}{l}\mathrm{BN}-1 \\
\mathrm{BN}-2 \\
\mathrm{BN}-3\end{array}$ & $\begin{array}{l}\text { Williams et al. (2005) } \\
\text { Williams et al. (2005) } \\
\text { Lorrey et al. (2010) }\end{array}$ \\
\hline 284 & Creighton's cave & -40.63 & 172.47 & New Zealand & 648 & $\mathrm{CN}-1$ & Williams et al. (2005) \\
\hline 285 & Disbelief cave & -38.82 & 177.52 & New Zealand & 649 & Disbelief & Lorrey et al. (2008) \\
\hline 286 & La Garma cave & 43.4306 & -3.6658 & Spain & $\begin{array}{l}650 \\
651 \\
652\end{array}$ & $\begin{array}{l}\text { GAR-01_drill } \\
\text { GAR-01_laser_d18O } \\
\text { GAR-01_laser_d13C }\end{array}$ & $\begin{array}{l}\text { Baldini et al. }(2015,2019) \\
\text { Baldini et al. (2015) } \\
\text { Baldini et al. (2015) }\end{array}$ \\
\hline 287 & Twin Forks cave & -40.63 & 172.48 & New Zealand & 653 & TF-2 & Williams et al. (2005) \\
\hline 288 & Wet Neck cave & -40.7 & 172.48 & New Zealand & $\begin{array}{l}654 \\
655\end{array}$ & $\begin{array}{l}\text { WN-4 } \\
\text { WN-11 }\end{array}$ & $\begin{array}{l}\text { Williams et al. (2005) } \\
\text { Williams et al. (2005) }\end{array}$ \\
\hline 289 & Gassel Tropfsteinhöhle & 47.8228 & 13.8428 & Austria & $\begin{array}{l}656 \\
657 \\
658 \\
659 \\
660 \\
661\end{array}$ & $\begin{array}{l}\text { GAS-12 } \\
\text { GAS-13 } \\
\text { GAS-22 } \\
\text { GAS-25 } \\
\text { GAS-27 } \\
\text { GAS-29 }\end{array}$ & $\begin{array}{l}\text { Moseley et al. (2020) } \\
\text { Moseley et al. (2020) } \\
\text { Moseley et al. (2020) } \\
\text { Moseley et al. (2020) } \\
\text { Moseley et al. (2020) } \\
\text { Moseley et al. (2020) }\end{array}$ \\
\hline 290 & Grete-Ruth Shaft & 47.5429 & 12.0272 & Austria & 662 & HUN-14 & Moseley et al. (2020) \\
\hline 292 & Limnon cave & 37.9605 & 22.1403 & Greece & 671 & KTR-2 & Peckover et al. (2019) \\
\hline 293 & Tham Doun Mai & 20.75 & 102.65 & Laos & 672 & TM-17 & Wang et al. (2019) \\
\hline 294 & Palco cave & 18.35 & -66.5 & Puerto Rico & 684 & $\mathrm{PA}-2 \mathrm{~b}$ & Rivera-Collazo et al. (2015) \\
\hline
\end{tabular}


(a) Age-depth model

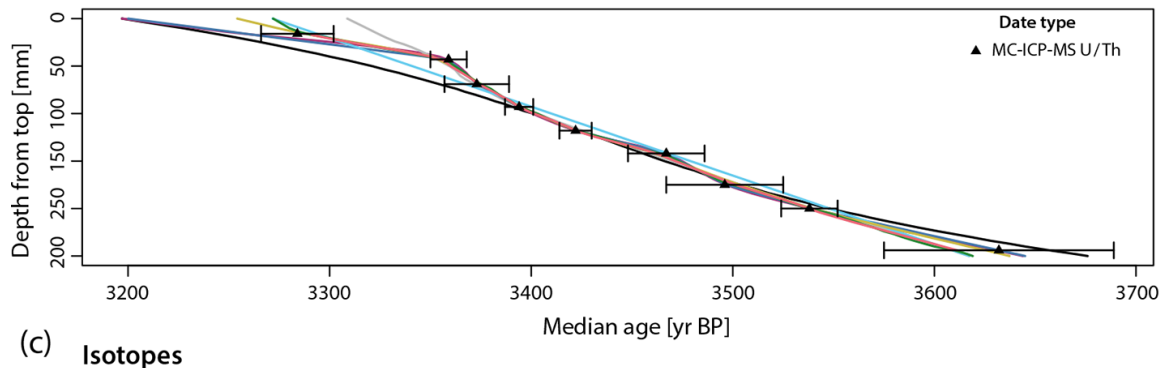

(c) Isotopes

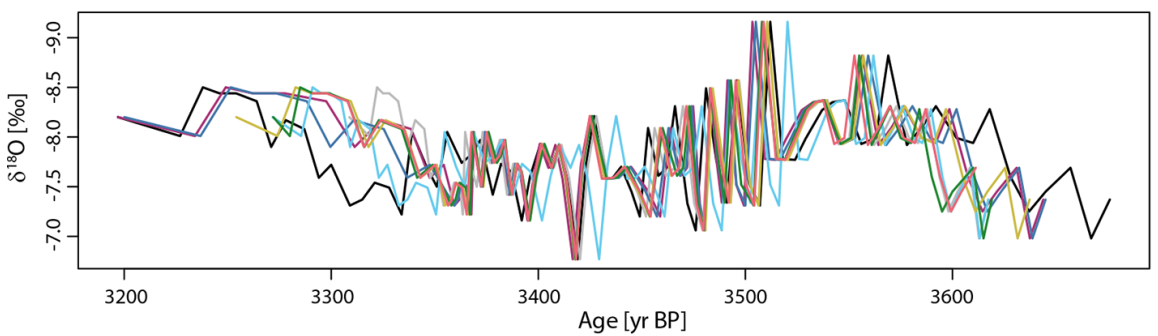

(b)

Age interquartile range (IQR)

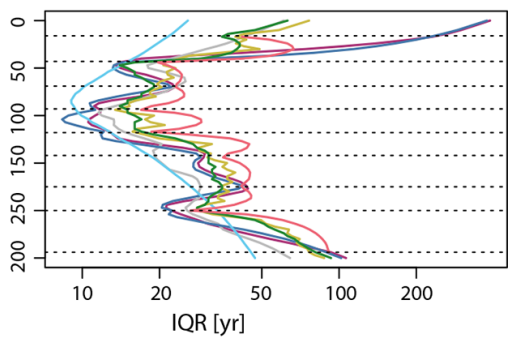

- Original AM: unknown

- Lin. interp. median age

- Lin. reg. median age

- Bchron median age

- Bacon median age

- OxCal median age

- copRa median age

- StalAge mean age

Figure 5. Illustration of the impact of the age model choice on reconstructed speleothem chronology illustrated by the KNI-51-H speleothem record (entity_id 342; Denniston et al., 2013b). Panel (a) shows the median and mean age estimates for each downcore sample from the different age models; (b) shows the interquartile range (IQR) of the ages. Dashed horizontal lines show the depths of the measured dates; (c) shows the isotopic record using the different age models.

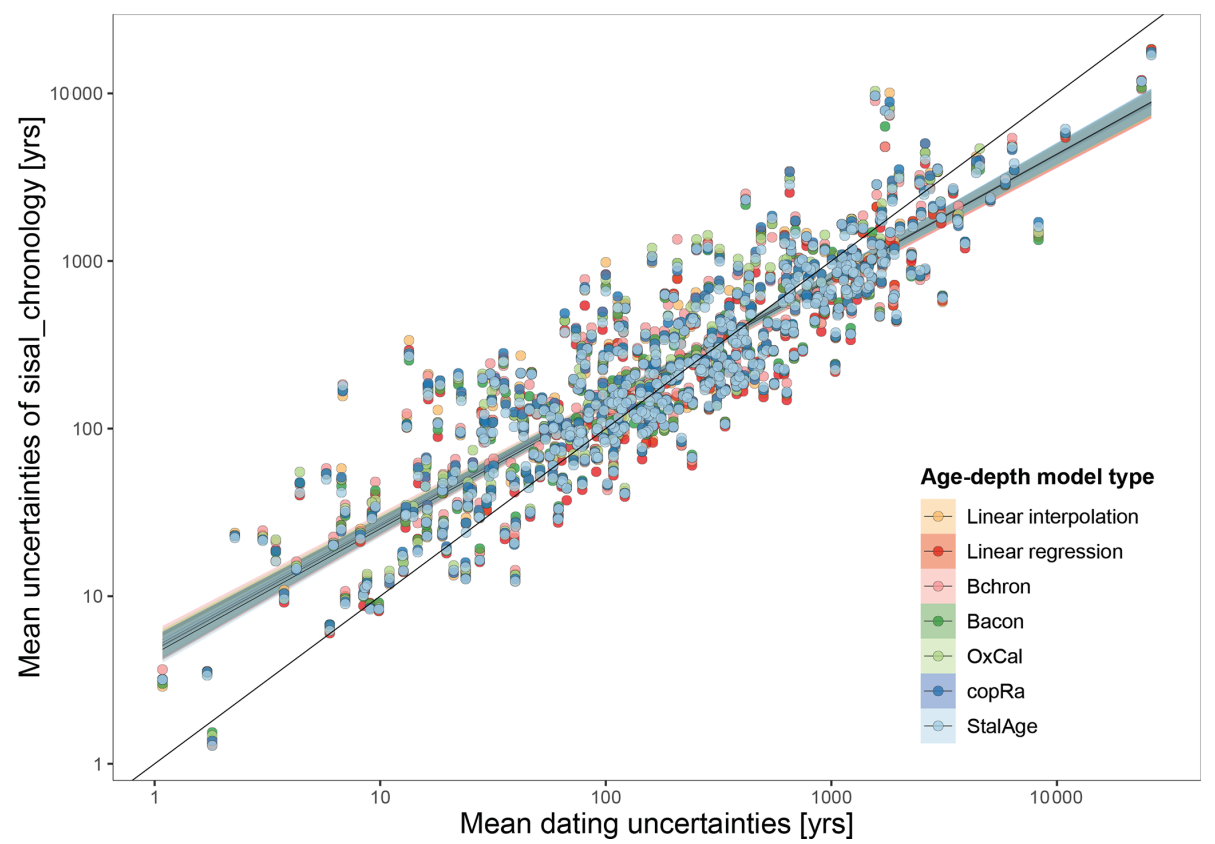

Figure 6. Scatterplot of average uncertainties in the sisal_chronology table and ${ }^{230} \mathrm{Th} / \mathrm{U}$ mean dating uncertainties for each entity and age-depth model technique. The $1: 1$ line is shown in black.

entities that pass all three criteria are considered successful. All age-depth models that satisfied Check 1 were also evaluated in an expert-based manual screening by 10 people. If more than two experts agreed that an individual age-depth model was unreliable or inconsistencies, such as large offsets between the original age model and the dates marked as "used", occurred, the model was not included in the SISAL chronology table. This automatic and expert-based quality control screening resulted in 2138 new age-depth models constructed for 503 SISAL entities. 


\section{Recommendation for the use of SISAL chronologies}

The original age-depth models for every entity are available in SISALv2. However, given the lack of age uncertainties for most of the records, we recommend considering the SISAL chronologies with their respective $95 \%$ confidence intervals whenever possible. No single age-depth modelling approach is successful for all entities, and we therefore recommend that all the methods for a specific entity are used together in visual and/or statistical comparisons. Depending on methodological choices, age-depth models compatible with the dating evidence can result in considerable temporal differences for transitions (Fig. 5). For analyses relying on the temporal alignment of records (e.g. cross-correlation), age-depth model uncertainties should be considered using the ensemble of compatible age-depth models as described in, for example, Mudelsee et al. (2012), Rehfeld and Kurths (2014) and Hu et al. (2017).

\section{Code and data availability}

The database is available in SQL and CSV format from https://doi.org/10.17864/1947.256 (Comas-Bru et al., 2020a). This dataset is licensed by the rights holder(s) under a Creative Commons Attribution 4.0 International License: https://creativecommons.org/licenses/by/4. 0/.The code used for constructing the linear interpolation, linear regression, Bchron, Bacon, copRa and Sta1Age age-depth models is available at https://github.com/ paleovar/SISAL.AM (last access: 23 July 2020; codes licensed by the right holder(s) under a GPL-3 license.). rBacon package (version 2.3.9.1) is available on CRAN (https://cran.r-project.org/web/packages/rbacon/ index.html; last access: 31 January 2020; this package is licensed by the right holder(s) under a GPL-3 license.). The code used to construct the OxCal age-depth models and trim the ensemble output to the last 2000 iterations is available at https://doi.org/10.5281/zenodo.3586280 (Amirnezhad-Mozhdehi and Comas-Bru, 2019). These codes are licensed by the right holder(s) under a Creative Commons Attribution 4.0 International. The ensembles are available at https://doi.org/10.5281/zenodo.3816804 (Rehfeld et al., 2020). These codes are licensed by the right holder(s) under a Creative Commons Attribution 4.0 International. The workbook used to submit data to SISAL and the codes for its quality assessment are available at https://doi.org/10.5281/zenodo.3631403 (Atsawawaranunt and Comas-Bru, 2020; scripts licensed by the right holder(s) under a Creative Commons Attribution 4.0 International.). The workbook is also available as a supplementary document of Comas-Bru and Harrison (2019) under a Creative Commons Attribution 4.0 International license. The codes to assess the dating table in SISALv2 are available at https://github.com/jensfohlmeister/QC_SISALv2_dating_ metadata (last access: 23 July 2020; licensed under a GPL-3 license) and https://doi.org/10.5281/zenodo.3631443 (Comas-Bru et al., 2020b; licensed under a Creative Commons Attribution 4.0 License). Details on the quality control assessments are available in the Supplement.

\section{Overview of database contents}

SISALv2 contains $353976 \delta^{18} \mathrm{O}$ and $200613 \delta^{13} \mathrm{C}$ measurements from 673 individual speleothem records and 18 composite records from 293 cave sites (Table 5, Fig. 2; Comas-Bru et al., 2020a). There are 20 records included in SISALv2 that are identified as being superseded and linked to the newer records; their original datasets are included in the database for completeness. This is an improvement of 235 records from SISALv $1 b$ (Atsawawaranunt et al., 2019; Comas-Bru et al., 2019; Table 6). SISALv2 represents $72 \%$ of the existing speleothem records identified by the SISAL working group and more than 3 times the number of speleothem records in the NCEI-NOAA repository ( $n=210$ as of November 2019; https://www.ncdc.noaa.gov/ data-access/paleoclimatology-data/datasets/speleothem (last access: 20 October 2020), which is the one most commonly used by the speleothem community to make their data publicly available. SISALv2 also contains nine records that have not been published or are only available in $\mathrm{PhD}$ theses.

The published age-depth models of all speleothems are accessible in the original_chronology metadata table, and our standardized age-depth models are available in the sisal_chronology table for 512 speleothems. Temporal uncertainties are now provided for $79 \%$ of the records in the SISAL database. This is a significantly larger number than in SISALv1b, where most age-depth models lacked temporal uncertainties. Most speleothem records show average ${ }^{230} \mathrm{Th} / \mathrm{U}$ age errors between 100 and 1000 years (Fig. 6), which are only slightly changed by using age-depth modelling software. Nevertheless, when comparing the mean uncertainties of the ${ }^{230} \mathrm{Th} / \mathrm{U}$ ages with those of their corresponding age-depth model, the slope between both parameters is smaller than 1 . This indicates that age-depth models tend to reduce uncertainties, especially when dating errors are large, while they increase uncertainties when ${ }^{230} \mathrm{Th} / \mathrm{U}$ age errors are small.

This second version of the SISAL database has an improved spatial coverage compared to SISALv1 (Atsawawaranunt et al., 2018b) and SISALv1b (Fig. 3; Atsawawaranunt et al., 2019). SISALv2 contains most published records from Oceania (80.2\%), Africa (73.7\%) and South America $(77.6 \%)$, but improvements are still possible in regions like the Middle East (42.3\%) and Asia (64.8\%; Table 6).

The temporal distribution of records for the past 2000 years is good, with 181 speleothems covering at least one-third of this period and 84 records covering the entire last 2000 years ( -68 to 2000 years BP) with an average res- 


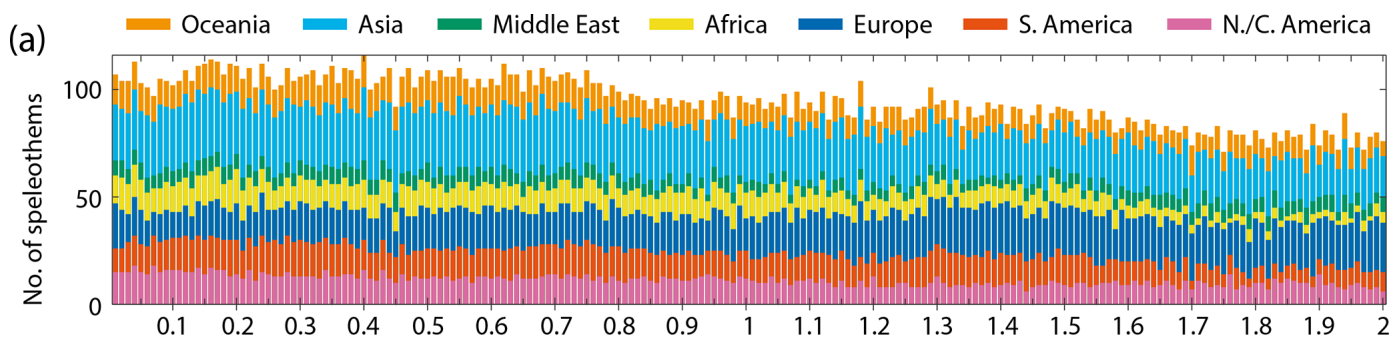

(b)

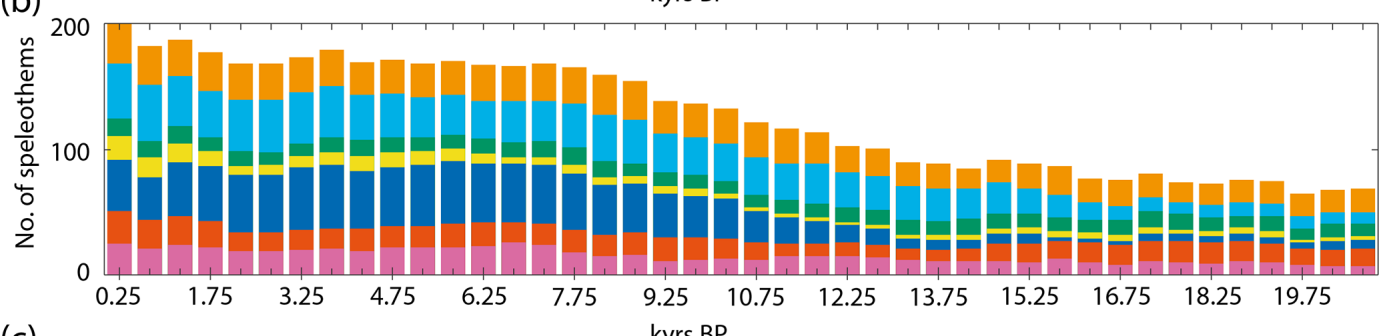

(c)

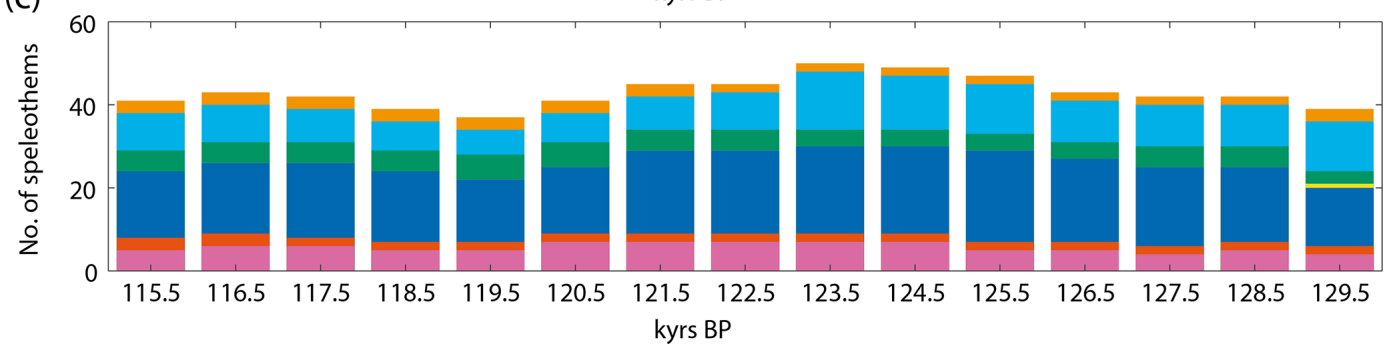

Figure 7. Global and regional temporal coverage of entities in the SISALv2. (a) Last 2000 years, with a bin size of 10 years; (b) last 21000 years, with a bin size of 500 years; (c) the period between 115000 and 130000 years BP, with a bin size of 1000 years. BP refers to "before present", where present is 1950 CE. Regions defined as in Table 7.

Table 6. Percentage of entities uploaded to the different versions of the SISAL database with respect to the number of records identified by the SISAL working group as of November 2019. The number of identified records includes potentially superseded speleothem records. Regions are defined as: Oceania $\left(-60^{\circ}<\right.$ Lat $<0^{\circ} ; 90^{\circ}<$ Long $\left.<180^{\circ}\right)$, Asia $\left(0^{\circ}<\right.$ Lat $<60^{\circ} ; 60^{\circ}<$ Long $\left.<130^{\circ}\right)$, Middle East $\left(7.6^{\circ}<\right.$ Lat $<50^{\circ} ; 26^{\circ}<$ Long $\left.<59^{\circ}\right)$, Africa $\left(-45^{\circ}<\right.$ Lat $<36.1^{\circ} ;-30^{\circ}<$ Long $<60^{\circ}$; with records in the Middle East region removed), Europe $\left(36.7^{\circ}<\right.$ Lat $<75^{\circ} ;-30^{\circ}<$ Long $<30^{\circ}$; plus Gibraltar and Siberian sites), South America (S. Am.; $-60^{\circ}<$ Lat $<8^{\circ} ;-150^{\circ}<$ Long $<$ $-30^{\circ}$ ), North and Central America (N./C. Am.; $8.1^{\circ}<$ Lat $<60^{\circ} ;-150^{\circ}<$ Long $<-50^{\circ}$ ).

\begin{tabular}{lrr|rr|rr}
\hline Region & Version 1 & \multicolumn{2}{|c|}{ Version 1b } & \multicolumn{2}{c}{ Version 2 } \\
& Entities & Sites & Entities & Sites & Entities & Sites \\
\hline Oceania & 47.7 & 36.7 & 56.8 & 51.0 & 80.2 & 69.4 \\
\hline Asia & 36.2 & 28.8 & 41.1 & 33.3 & 64.8 & 48.5 \\
\hline Middle East & 21.2 & 31.1 & 28.8 & 35.6 & 42.3 & 48.9 \\
\hline Africa & 63.2 & 62.5 & 63.2 & 62.5 & 73.7 & 87.5 \\
\hline Europe & 48.0 & 51.9 & 54.6 & 58.7 & 75.3 & 77.9 \\
\hline S. Am. & 30.6 & 39.5 & 40.8 & 50.0 & 77.6 & 73.7 \\
\hline N./C. Am. & 35.7 & 36.7 & 51.8 & 56.7 & 70.5 & 73.3 \\
\hline
\end{tabular}


olution of 20 isotope measurements in every 100 -year slice (Fig. 7a). There are 182 records that cover at least one-third of the Holocene (last 11700 years BP), with 37 of these covering the whole period with at least one isotope measurement in every 500-year period (Fig. 7b). There are 84 entities during the deglaciation period (21000 to 11700 years BP) with at least one measurement in every 500-year time period (Fig. 7b). The Last Interglacial (130 000 to 115000 years BP) is covered by 47 speleothem records that record at least onethird of this period with, on average, 25 isotope measurements in every 1000-year time slice (Fig. 7c).

This updated SISALv2 database now not only provides the basis for comparing a large number of speleothem-based environmental reconstructions on a regional to a global scale but also allows for comprehensive analyses of stable-isotope records on various timescales, from multi-decadal to orbital.

Supplement. The supplement related to this article is available online at: https://doi.org/10.5194/essd-12-2579-2020-supplement.

Team list. The following SISAL working group members contributed with either data or age-modelling advice to SISALv2: James Apaéstegui (Instituto Geofísico del Perú, Lima, Peru), Lisa M. Baldini (School of Health and Life Sciences, Teesside University, Middlesbrough, UK), Shraddha Band (Geoscience Department, National Taiwan University, No. 1, Sect. 4, Roosevelt Road, Taipei 106, Taiwan), Maarten Blaauw (School of Natural and Built Environment, Queen's University Belfast, UK), Ronny Boch (Institute of Applied Geosciences, Graz University of Technology, Rechbauerstraße 12, 8010 Graz, Austria), Andrea Borsato (School of Environmental and Life Sciences, University of Newcastle, Challaghan 2308, NSW, Australia), Alexander Budsky (Institute for Geosciences, Johannes Gutenberg University Mainz, Johann-Joachim-Becher-Weg 21, 55128 Mainz, Germany), Maria Gracia Bustamante Rosell (Department of Geology and Environmental Science, University of Pittsburgh, USA), Sakonvan Chawchai (Department of Geology, Faculty of Science, Chulalongkorn University, Bangkok 10330, Thailand), Silviu Constantin (Emil Racovita Institute of Speleology, Bucharest, Romania, and Centro Nacional de Investigación sobre la Evolución Humana, CENIEH, Burgos, Spain), Rhawn Denniston (Department of Geology, Cornell College, Mount Vernon, IA 52314, USA), Virgil Dragusin (Emil Racovita Institute of Speleology, 010986, Strada Frumoasă 31, Bucharest, Romania), Russell Drysdale (School of Geography, University of Melbourne, Melbourne, Australia), Oana Dumitru (Karst Research Group, School of Geosciences, University of South Florida, 4202 E. Fowler Ave., NES 107, Tampa, FL 33620, USA), Amy Frappier (Department of Geosciences, Skidmore College, Saratoga Springs, New York, USA), Naveen Gandhi (Indian Institute of Tropical Meteorology, Homi Bhabha Road, Pashan, Pune-411008, India), Pawan Gautam (Centre for Earth, Ocean and Atmospheric Sciences, University of Hyderabad, India; now at Geological Survey of India, Northern Region, India), Li Hanying (Institute of Global Environmental Change, Xi' an Jiaotong University, China), Ilaria Isola (Istituto Nazionale di Geofisica e Vulcanologia, Pisa, Italy), Xiuyang Jiang (College of Geography Science, Fujian
Normal University, Fuzhou 350007, China), Zhao Jingyao (Institute of Global Environmental Change, Xi' an Jiaotong University, China), Kathleen Johnson (Dept. of Earth System Science, University of California, Irvine, 3200 Croul Hall, Irvine, CA 92697 USA), Vanessa Johnston (Research Centre of the Slovenian Academy of Sciences and Arts ZRC SAZU, Novi trg 2, Ljubljana, Slovenia), Gayatri Kathayat (Institute of Global Environmental Change, Xi' an Jiaotong University, China), Jennifer Klose (Institut für Geowissenschaften, Johannes Gutenberg University Mainz, Germany), Claire Krause (Geoscience Australia, Canberra, Australian Capital Territory, 2601, Australia), Matthew Lachniet (Department of Geoscience, University of Nevada Las Vegas, Las Vegas, NV 89154, USA), Amzad Laskar (Geosciences Division, Physical Research Laboratory, Navrangpura, Ahmedabad 380009, India), Stein-Erik Lauritzen (University of Bergen, Earth science, Norway), Nina Lončar (University of Zadar, Department of Geography, Trg Kneza Višeslava 9, 23000, Zadar, Croatia), Gina Moseley (Institute of Geology, University of Innsbruck, Innrain 52, 6020 Innsbruck, Austria), Allu C. Narayana (Centre for Earth, Ocean and Atmospheric Sciences, University of Hyderabad, India), Bogdan P. Onac (University of South Florida, School of Geosciences, 4202 E Fowler Ave, Tampa, FL 33620, USA and Emil Racoviță Institute of Speleology, Cluj-Napoca, Romania), Jacek Pawlak (Institute of Geological Sciences, Polish Academy of Sciences, 00-818, Twarda 51/55, Warsaw, Poland), Christopher Bronk Ramsey (Research Laboratory for Archaeology and the History of Art, Oxford University, Oxford, UK), Isabel Rivera-Collazo (Department of Anthropology and the Scripps Institution of Oceanography, UC San Diego, USA), Carlos Rossi (Dept. Petrología y Geoquímica, Facultad de Ciencias Geologicas, Universidad Complutense, Madrid, Spain), Peter J. Rowe (School of Environmental Sciences, University of East Anglia, NR4 7TJ, Norwich Research Park, Norwich, UK), Nicolás M. Stríkis (Department of Geochemistry, Universidade Federal Fluminense, Niterói, Brazil), Liangcheng Tan (State Key Laboratory of Loess and Quaternary Geology, Institute of Earth Environment, Chinese Academy of Sciences, Xi' an 710075, China), Sophie Verheyden (Politique scientifique fédérale belge BELSPO, Bvd. Simon Bolivar 30, 1000 Brussels, Belgium), Hubert Vonhof (Max Planck Institute for Chemistry, Mainz, Germany), Michael Weber (Johannes Gutenberg University Mainz, Germany), Kathleen Wendt (Institute of Geology, University of Innsbruck, Austria), Paul Wilcox (Institute of Geology, University of Innsbruck, Austria), Amos Winter (Dept. of Earth and Environmental Systems, Indiana State University, USA), Jiangying Wu (School of Geography, Nanjing Normal University, Nanjing, China), Peter Wynn (Lancaster Environment Centre, University of Lancaster, Lancaster, LA1 4YQ, UK) and Madhusudan G. Yadava (Geosciences Division, Physical Research Laboratory, Navrangpura, Ahmedabad 380009, India).

Author contributions. LCB is the coordinator of the SISAL working group. LCB, SPH and KR designed the new version of the database. KR coordinated the construction of the new age-depth models except OxCal. All age-depth models except OxCal were run by $\mathrm{CR}$ and KR. LCB coordinated the construction of the OxCal age-depth models, which were run by SAM and LCB. LCB implemented the changes in the $\mathrm{v} 2$ of the database with the assistance of KA. SMA, YAB, AB, YB, MB, AC, MD, AD, BD, IGH, JH, NK, ZK, FAL, AL, BM, VFN, JO, CPM, NSc, NSi, BMW, SW and HZ 
coordinated the regional data collection and the age model screening. SFMB, MB and DS provided support for COPRA, Bacon and StalAge, respectively. JF assisted in the quality control procedure of the SISAL database. Figures 1, 4 and 5 were created by CR and KR. Figures 2, 3 and 6 were created by LCB. All authors listed as "SISAL working group members" provided data for this version of the database and/or helped to complete data entry. The first draft of the paper was written by LCB with input by KR and SPH, and all authors contributed to the final version.

Competing interests. The authors declare that they have no conflict of interest.

Acknowledgements. This study was undertaken by SISAL (Speleothem Isotopes Synthesis and Analysis), a working group of the Past Global Changes (PAGES) project, which in turn received support from the Swiss Academy of Sciences and the Chinese Academy of Sciences. We thank SISAL members who contributed their published data to the database and provided additional information when necessary. We thank all experts who engaged in the age-depth model evaluation. The authors would like to acknowledge Avner Ayalon, Jordi López, Bahadur Singh Kotlia and Dennis Rupprecht.

Financial support. The design and creation of v2 of the database were supported by funding to Sandy P. Harrison from the ERCfunded project GC2.0 (Global Change 2.0: Unlocking the past for a clearer future; grant no. 694481) and the Geological Survey Ireland Short Call 2017 (Developing a toolkit for model evaluation using speleothem isotope data; grant no. 2017-SC-056) award to Laia Comas-Bru. Sandy P. Harrison and Laia Comas-Bru received additional support from the ERC-funded project GC2.0 and from the JPI-Belmont project "PAlaeo-Constraints on Monsoon Evolution and Dynamics (PACMEDY)" through the UK Natural Environmental Research Council (NERC). Laia Comas-Bru and Belen Martrat received support from the CSIC scientific international collaboration programme I-LINKA20102 IBCC-lo2k. Kira Rehfeld and Denis Scholz acknowledge support by the Deutsche Forschungsgemeinschaft (DFG; codes RE3994/2-1 and SCHO 1274/11-1).

Review statement. This paper was edited by Thomas Blunier and reviewed by Oliver Bothe and Judson W. Partin.

\section{References}

Ait Brahim, Y., Wassenburg, J. A., Cruz, F. W., Sifeddine, A., Scholz, D., Bouchaou, L., Dassie, E. P., Jochum, K. P., Edwards, R. L., and Cheng, H.: Multi-decadal to centennial hydroclimate variability and linkage to solar forcing in the Western Mediterranean during the last 1000 years, Sci. Rep., 8, 174466, https://doi.org/10.1038/s41598-018-35498-x, 2018.

Ait Brahim, Y., Wassenburg, J. A., Sha, L., Cruz, F. W., Deininger, M., Sifeddine, A., Bouchaou, L., Spötl, C., Edwards, R. L., and Cheng, H.: North Atlantic Ice-Rafting, Ocean and Atmospheric Circulation During the Holocene: Insights From Western Mediterranean Speleothems, Geophys. Res. Lett., 46, GL082405, https://doi.org/10.1029/2019GL082405, 2019.

Amin Al-Manmi, D. A. M., Ismaeel, S. B., and Altaweel, M.: Reconstruction of palaeoclimate in Shalaii Cave, SE of Sangaw, Kurdistan Province of Iraq, Palaeogeogr. Palaeocl., 524, 262272, https://doi.org/10.1016/J.PALAEO.2019.03.044, 2019.

Amirnezhad-Mozhdehi, S. and Comas-Bru, L.: MATLAB scripts to produce OxCal chronologies for SISAL database (scripts V1) (Version 1.0), Zenodo, https://doi.org/10.5281/zenodo.3586280, 2019.

Apaestegui, J., Cruz, F. W., Vuille, M., Fohlmeister, J., Espinoza, J. C., Sifeddine, A., Strikis, N., Guyot, J. L., Ventura, R., Cheng, H., and Edwards, R. L.: Precipitation changes over the eastern Bolivian Andes inferred from speleothem (delta O-18) records for the last 1400 years, Earth Planet. Sc. Lett., 494, 124134, https://doi.org/10.1016/j.eps1.2018.04.048, 2018.

Asmerom, Y., Polyak, V., Burns, S., and Rassmussen, J.: Solar forcing of Holocene climate: New insights from a speleothem record, southwestern United States, Geology, 35, 14, https://doi.org/10.1130/G22865A.1, 2007.

Asmerom, Y., Polyak, V. J., Rasmussen, J. B. T., Burns, S. J., and Lachniet, M.: Multidecadal to multicentury scale collapses of Northern Hemisphere monsoons over the past millennium, P. Natl. Acad. Sci. USA, 110, 9651-9656, https://doi.org/10.1073/pnas.1214870110, 2013.

Atsawawaranunt, K., Comas-Bru, L., Amirnezhad Mozhdehi, S., Deininger, M., Harrison, S. P., Baker, A., Boyd, M., Kaushal, N., Ahmad, S. M., Ait Brahim, Y., Arienzo, M., Bajo, P., Braun, K., Burstyn, Y., Chawchai, S., Duan, W., Hatvani, I. G., Hu, J., Kern, Z., Labuhn, I., Lachniet, M., Lechleitner, F. A., Lorrey, A., Pérez-Mejías, C., Pickering, R., Scroxton, N., and SISAL Working Group Members: The SISAL database: a global resource to document oxygen and carbon isotope records from speleothems, Earth Syst. Sci. Data, 10, 1687-1713, https://doi.org/10.5194/essd-10-1687-2018, 2018a.

Atsawawaranunt, K., Harrison, S., and Comas-Bru, L.: SISAL (Speleothem Isotopes Synthesis and AnaLysis Working Group) database Version 1.0, University of Reading, Dataset, https://doi.org/10.17864/1947.147, 2018b.

Atsawawaranunt, K., Harrison, S., and Comas-Bru, L.: SISAL (Speleothem Isotopes Synthesis and AnaLysis Working Group) database Version 1b, University of Reading, Dataset, https://doi.org/10.17864/1947.189, 2019.

Badertscher, S., Fleitmann, D., Cheng, H., Edwards, R. L., Göktürk, O. M., Zumbühl, A., Leuenberger, M., and Tüysüz, O.: Pleistocene water intrusions from the Mediterranean and Caspian seas into the Black Sea, Nat. Geosci., 4, 236-239, https://doi.org/10.1038/ngeo1106, 2011.

Baldini, L. M., McDermott, F., Baldini, J. U. L., Arias, P., Cueto, M., Fairchild, I. J., Hoffmann, D. L., Mattey, D. P., Muller, W., Nita, D. C., Ontanon, R., GarciaMonco, C., and Richards, D. A.: Regional temperature, atmospheric circulation, and sea-ice variability within the Younger Dryas Event constrained using a speleothem from northern Iberia, Earth Planet. Sc. Lett., 419, 101-110, https://doi.org/10.1016/j.epsl.2015.03.015, 2015.

Baldini, L. M., Baldini, J. U. L., McDermott, F., Arias, P., Cueto, M., Fairchild, I. J., Hoffmann, D. L., Mattey, D. P., 
Müller, W., Nita, D. C., Ontañón, R., Garciá-Moncó, C., and Richards, D. A.: North Iberian temperature and rainfall seasonality over the Younger Dryas and Holocene, Quaternary Sci. Rev., 226, 105998, https://doi.org/10.1016/j.quascirev.2019.105998, 2019.

Band, S., Yadava, M. G., Lone, M. A., Shen, C. C., Sree, K., and Ramesh, R.: High-resolution mid-Holocene Indian Summer Monsoon recorded in a stalagmite from the Kotumsar Cave, Central India, Quatern. Int., 479, 19-24, https://doi.org/10.1016/j.quaint.2018.01.026, 2018.

Bar-Matthews, M., Ayalon, A., Gilmour, M., Matthews, A., and Hawkesworth, C. J.: Sea-land oxygen isotopic relationships from planktonic foraminifera and speleothems in the Eastern Mediterranean region and their implication for paleorainfall during interglacial intervals, Geochim. Cosmochim. Ac., 67, 31813199, https://doi.org/10.1016/S0016-7037(02)01031-1, 2003.

Blaauw, M.: Methods and code for "classical" age-modelling of radiocarbon sequences, Quat. Geochronol., 5, 512-518, https://doi.org/10.1016/j.quageo.2010.01.002, 2010.

Blaauw, M. and Christen, J. A.: Flexible paleoclimate age-depth models using an autoregressive gamma process, Bayesian Anal., 6, 457-474, https://doi.org/10.1214/11-ba618, 2011.

Blaauw, M., Christen, J. A., Vazquez, J. E., Belding, T., Theiler, J., Gough, B., and Karney, C.: rbacon: Age-depth modelling using Bayesian statistics: $\mathrm{R}$ package, version 2.3.9.1, last access: https://cran.r-project.org/web/packages/rbacon/, last access: 20 October 2019.

Braun, K., Nehme, C., Pickering, R., Rogerson, M., and Scroxton, N.: A Window into Africa's Past Hydroclimates: The SISAL_v1 Database Contribution, Quaternary, 2, 4, https://doi.org/10.3390/quat2010004, 2019a.

Braun, K., Bar-Matthews, M., Matthews, A., Ayalon, A., Cowling, R. M., Karkanas, P., Fisher, E. C., Dyez, K., Zilberman, T., and Marean, C. W.: Late Pleistocene records of speleothem stable isotopic compositions from Pinnacle Point on the South African south coast, Quaternary Res., 91, 265-288, https://doi.org/10.1017/qua.2018.61, 2019b.

Breitenbach, S. F. M., Rehfeld, K., Goswami, B., Baldini, J. U. L., Ridley, H. E., Kennett, D. J., Prufer, K. M., Aquino, V. V., Asmerom, Y., Polyak, V. J., Cheng, H., Kurths, J., and Marwan, N.: COnstructing Proxy Records from Age models (COPRA), Clim. Past, 8, 1765-1779, https://doi.org/10.5194/cp-81765-2012, 2012.

Breitenbach, S. F. M., Plessen, B., Waltgenbach, S., Tjallingii, R., Leonhardt, J., Jochum, K. P., Meyer, H., Goswami, B., Marwan, N., and Scholz, D.: Holocene interaction of maritime and continental climate in Central Europe: New speleothem evidence from Central Germany, Global Planet. Change, 176, 144-161, https://doi.org/10.1016/J.GLOPLACHA.2019.03.007, 2019.

Bronk Ramsey, C.: Deposition models for chronological records, Quaternary Sci. Rev., 27, 42-60, https://doi.org/10.1016/j.quascirev.2007.01.019, 2008.

Bronk Ramsey, C.: Bayesian analysis of radiocarbon dates, Radiocarbon, 51, 337-360,: https://doi.org/10.1017/S0033822200033865, 2009.

Bronk Ramsey, C. and Lee, S.: Recent and planned developments of the program OxCal, Radiocarbon, 55, 720-730, https://doi.org/10.2458/azu_js_rc.55.16215, 2013.
Budsky, A., Scholz, D., Wassenburg, J. A., Mertz-Kraus, R., Spötl, C., Riechelmann, D. F. C., Gibert, L., Jochum, K. P., and Andreae, M. O.: Speleothem $\delta^{13} \mathrm{C}$ record suggests enhanced spring/summer drought in south-eastern Spain between 9.7 and $7.8 \mathrm{ka}$ - A circum-Western Mediterranean anomaly?, Holocene, 29, 1113-1133, https://doi.org/10.1177/0959683619838021, 2019.

Burns, S. J., Fleitmann, D., Matter, A., Kramers, J., and AlSubbary, A. A.: Indian Ocean Climate and an Absolute Chronology over Dansgaard/Oeschger Events 9 to 13, Science, 301, 1365-1367, https://doi.org/10.1126/science.1086227, 2003.

Burns, S. J., Fleitmann, D., Matter, A., Kramers, J., and AlSubbary, A. A.: Corrections and Clarifications, Science, 305, 1567a-1567a, https://doi.org/10.1126/science.305.5690.1567a, 2004.

Burns, S. J., Welsh, L. K., Scroxton, N., Cheng, H., and Edwards, R. L.: Millennial and orbital scale variability of the South American Monsoon during the penultimate glacial period, Sci. Rep., 9, 1234, https://doi.org/10.1038/s41598-018-37854-3, 2019.

Burstyn, Y., Martrat, B., Lopez, F. J., Iriarte, E., Jacobson, J. M., Lone, A. M., and Deininger, M.: Speleothems from the Middle East: An Example of Water Limited Environments in the SISAL Database, Quaternary, 2, 16, https://doi.org/10.3390/quat2020016, 2019.

Cai, Y. J., Chiang, J. C. H., Breitenbach, S. F. M., Tan, L. C., Cheng, H., Edwards, R. L., and An, Z. S.: Holocene moisture changes in western China, Central Asia, inferred from stalagmites, Quaternary Sci. Rev., 158, 15-28, https://doi.org/10.1016/j.quascirev.2016.12.014, 2017.

Carolin, S. A., Cobb, K. M., Lynch-Stieglitz, J., Moerman, J. W., Partin, J. W., Lejau, S., Malang, J., Clark, B., Tuen, A. A., and Adkins, J. F.: Northern Borneo stalagmite records reveal West Pacific hydroclimate across MIS 5 and 6, Earth Planet. Sc. Lett., 439, 182-193, https://doi.org/10.1016/j.epsl.2016.01.028, 2016.

Carolin, S. A., Walker, R. T., Day, C. C., Ersek, V., Sloan, R. A., Dee, M. W., Talebian, M., and Henderson, G. M.: Precise timing of abrupt increase in dust activity in the Middle East coincident with 4.2 ka social change, P. Natl. Acad. Sci. USA, 116, 67-72, https://doi.org/10.1073/PNAS.1808103115, 2019.

Cheng, H., Edwards, R. L., Wan, Y. J., Ko, X. G., Ming, Y. F., Kelly, M. J., Wang, X. F., Gallup, C. D., and Liu, W. G.: A penultimate glacial monsoon record from Hulu Cave and two-phase glacial terminations, Geology, 34, 217-220, https://doi.org/10.1130/g22289.1, 2006.

Cheng, H., Fleitmann, D., Edwards, R. L., Wang, X., Cruz, F. W., Auler, A. S., Mangini, A., Wang, Y., Kong, X., Burns, S. J., and Matter, A.: Timing and structure of the $8.2 \mathrm{kyr}$ B.P. event inferred from $\delta^{18} \mathrm{O}$ records of stalagmites from China, Oman, and Brazil, Geology, 37, 1007-1010, https://doi.org/10.1130/G30126A.1, 2009.

Cheng, H., Sinha, A., Cruz, F. W., Wang, X., Edwards, R. L., d'Horta, F. M., Ribas, C. C., Vuille, M., Stott, L. D., and Auler, A. S.: Climate change patterns in Amazonia and biodiversity, Nat. Commun., 4, 1411, https://doi.org/10.1038/ncomms2415, 2013.

Cheng, H., Springer, G. S., Sinha, A., Hardt, B. F., Yi, L., Li, H., Tian, Y., Li, X., Rowe, H. D., Kathayat, G., Ning, Y., and Edwards, R. L.: Eastern North American climate in 
phase with fall insolation throughout the last three glacialinterglacial cycles, Earth Planet. Sc. Lett., 522, 125-134, https://doi.org/10.1016/j.epsl.2019.06.029, 2019.

Columbu, A., Spötl, C., De Waele, J., Yu, T.-L., Shen, C.-C., and Gázquez, F.: A long record of MIS 7 and MIS 5 climate and environment from a western Mediterranean speleothem (SW Sardinia, Italy), Quaternary Sci. Rev., 220, 230-243, https://doi.org/10.1016/J.QUASCIREV.2019.07.023, 2019.

Comas-Bru, L. and Harrison, S. P.: SISAL: Bringing added value to speleothem research, Quaternary, 2, 7, https://doi.org/10.3390/quat2010007, 2019.

Comas-Bru, L., Harrison, S. P., Werner, M., Rehfeld, K., Scroxton, N., Veiga-Pires, C., and SISAL working group members: Evaluating model outputs using integrated global speleothem records of climate change since the last glacial, Clim. Past, 15, 1557-1579, https://doi.org/10.5194/cp-15-1557-2019, 2019.

Comas-Bru, L., Atsawawaranunt, K., Harrison, S. P. and SISAL Working Group members: SISAL (Speleothem Isotopes Synthesis and AnaLysis Working Group) database version 2.0, University of Reading, Dataset, https://doi.org/10.17864/1947.256, 2020a.

Comas-Bru, L., Deininger, M., Fohlmeister, J., Baker, A., McDermott, F., and Scholz, D.: Quality control of the dating information table in the SISAL database, Zenodo, https://doi.org/10.5281/zenodo.3631443, 2020b.

Cruz, F. W., Burns, S. J., Karmann, I., Sharp, W. D., and Vuille, M.: Reconstruction of regional atmospheric circulation features during the late Pleistocene in subtropical Brazil from oxygen isotope composition of speleothems, Earth Planet. Sc. Lett., 248, 495-507, https://doi.org/10.1016/J.EPSL.2006.06.019, 2006.

Czuppon, G., Demeny, A., Leel-Ossy, S., Ovari, M., Molnar, M., Stieber, J., Kiss, K., Karman, K., Suranyi, G., and Haszpra, L.: Cave monitoring in the Beke and Baradla caves (Northeastern Hungary): implications for the conditions for the formation cave carbonates, Int. J. Speleol., 47, 13-28, https://doi.org/10.5038/1827-806x.47.1.2110, 2018.

Deininger, M., Ward, M. B., Novello, F. V., and Cruz, W. F.: Late Quaternary Variations in the South American Monsoon System as Inferred by Speleothems - New Perspectives Using the SISAL Database, Quaternary, 2, 6, https://doi.org/10.3390/quat2010006, 2019.

Demény, A., Kern, Z., Németh, A., Frisia, S., Hatvani, I. G., Czuppon, G., Leél-Ôssy, S., Molnár, M., Óvári, M., Surányi, G., Gilli, A., Wu, C.-C., and Shen, C.-C.: North Atlantic influences on climate conditions in East-Central Europe in the late Holocene reflected by flowstone compositions, Quatern. Int., 512, 99-112, https://doi.org/10.1016/J.QUAINT.2019.02.014, 2019.

Denniston, R. F., Asmerom, Y., Lachniet, M., Polyak, V. J., Hope, P., An, N., Rodzinyak, K., and Humphreys, W. F.: A Last Glacial Maximum through middle Holocene stalagmite record of coastal Western Australia climate, Quaternary Sci. Rev., 77, 101112, https://doi.org/10.1016/j.quascirev.2013.07.002, 2013a.

Denniston, R. F., Wyrwoll, K.-H., Polyak, V. J., Brown, J. R., Asmerom, Y., Wanamaker, A. D., LaPointe, Z., Ellerbroek, R., Barthelmes, M., Cleary, D., Cugley, J., Woods, D., and Humphreys, W. F.: A Stalagmite record of Holocene Indonesian-Australian summer monsoon variability from the Australian tropics, Quaternary Sci. Rev., 78, 155-168, https://doi.org/10.1016/J.QUASCIREV.2013.08.004, 2013b.

Denniston, R. F., Asmerom, Y., Polyak, V. J., Wanamaker, A. D., Ummenhofer, C. C., Humphreys, W. F., Cugley, J., Woods, D., and Lucker, S.: Decoupling of monsoon activity across the northern and southern Indo-Pacific during the Late Glacial, Quaternary Sci. Rev., 176, 101-105, https://doi.org/10.1016/J.QUASCIREV.2017.09.014, 2017.

Denniston, R. F., Houts, A. N., Asmerom, Y., Wanamaker Jr., A. D., Haws, J. A., Polyak, V. J., Thatcher, D. L., Altan-Ochir, S., Borowske, A. C., Breitenbach, S. F. M., Ummenhofer, C. C., Regala, F. T., Benedetti, M. M., and Bicho, N. F.: A stalagmite test of North Atlantic SST and Iberian hydroclimate linkages over the last two glacial cycles, Clim. Past, 14, 1893-1913, https://doi.org/10.5194/cp-14-1893-2018, 2018.

Dong, J., Shen, C.-C., Kong, X., Wu, C.-C., Hu, H.-M., Ren, H., and Wang, Y.: Rapid retreat of the East Asian summer monsoon in the middle Holocene and a millennial weak monsoon interval at $9 \mathrm{ka}$ in northern China, J. Asian Earth Sci., 151, 31-39, https://doi.org/10.1016/J.JSEAES.2017.10.016, 2018.

Dumitru, O. A., Onac, B. P., Polyak, V. J., Wynn, J. G., Asmerom, Y., and Fornos, J. J.: Climate variability in the western Mediterranean between 121 and $67 \mathrm{ka}$ derived from a Mallorcan speleothem record, Palaeogeogr. Palaeocl., 506, 128-138, https://doi.org/10.1016/j.palaeo.2018.06.028, 2018.

El-Shenawy, M. I., Kim, S. T., Schwarcz, H. P., Asmerom, Y., and Polyak, V. J.: Speleothem evidence for the greening of the Sahara and its implications for the early human dispersal out of sub-Saharan Africa, Quaternary Sci. Rev., 188, 67-76, https://doi.org/10.1016/j.quascirev.2018.03.016, 2018.

Fleitmann, D., Cheng, H., Badertscher, S., Edwards, R. L., Mudelsee, M., Göktürk, O. M., Fankhauser, A., Pickering, R., Raible, C. C., Matter, A., Kramers, J., and Tüysüz, O.: Timing and climatic impact of Greenland interstadials recorded in stalagmites from northern Turkey, Geophys. Res. Lett., 36, L19707L19707, https://doi.org/10.1029/2009GL040050, 2009.

Flohr, P., Fleitmann, D., Zorita, E., Sadekov, A., Cheng, H., Bosomworth, M., Edwards, L., Matthews, W., and Matthews, R.: Late Holocene droughts in the Fertile Crescent recorded in a speleothem from northern Iraq, Geophys. Res. Lett., 44, 15281536, https://doi.org/10.1002/2016GL071786, 2017.

Frappier, A., Sahagian, D., González, L. A., and Carpenter, S. J.: El Nino Events Recorded by Stalagmite Carbon Isotopes, Science, 298, 565-565, https://doi.org/10.1126/science.1076446, 2002.

Frappier, A. B., Sahagian, D., Carpenter, S. J., Gonzalez, L. A., and Frappier, B. R.: Stalagmite stable isotope record of recent tropical cyclone events, Geology, 35, 111-114, https://doi.org/10.1130/g23145a.1, 2007.

Gautam, P. K., Narayana, A. C., Band, S. T., Yadava, M. G., Ramesh, R., Wu, C.-C., and Shen, C.-C.: High-resolution reconstruction of Indian summer monsoon during the BøllingAllerød from a central Indian stalagmite, Palaeogeogr. Palaeocl., 514, 567-576, https://doi.org/10.1016/J.PALAEO.2018.11.006, 2019.

Göktürk, O. M., Fleitmann, D., Badertscher, S., Cheng, H., Edwards, R. L., Leuenberger, M., Fankhauser, A., Tüysüz, O., and Kramers, J.: Climate on the southern Black Sea coast during the Holocene: implications from the Sofu- 
lar Cave record, Quaternary Sci. Rev., 30, 2433-2445, https://doi.org/10.1016/J.QUASCIREV.2011.05.007, 2011.

Goldscheider, N., Chen, Z., Auler, A. S., Bakalowicz, M., Broda, S., Drew, D., Hartmann, J., Jiang, G., Moosdorf, N., Stevanovic, Z., and Veni, G.: Global distribution of carbonate rocks and karst water resources, Hydrogeol. J., 28, 1661-1677, https://doi.org/10.1007/s10040-020-02139-5, 2020.

Haslett, J. and Parnell, A.: A simple monotone process with application to radiocarbon-dated depth chronologies, J. R. Stat. Soc. C-Appl., 57, 399-418, https://doi.org/10.1111/j.14679876.2008.00623.x, 2008.

$\mathrm{Hu}$, J, Emile-Geay J., and Partin J.: Correlation-based interpretations of paleoclimate data-where statistics meet past climates, Earth Planet. Sc. Lett., 459, 362-371, https://doi.org/10.1016/j.epsl.2016.11.048, 2017.

Huguet, C., Routh, J., Fietz, S., Lone, M. A., Kalpana, M. S., Ghosh, P., Mangini, A., Kumar, V., and Rangarajan, R.: Temperature and Monsoon Tango in a Tropical Stalagmite: Last Glacial-Interglacial Climate Dynamics, Sci. Rep., 8, 5386, https://doi.org/10.1038/s41598-018-23606-w, 2018.

Isola, I., Zanchetta, G., Drysdale, R. N., Regattieri, E., Bini, M., Bajo, P., Hellstrom, J. C., Baneschi, I., Lionello, P., Woodhead, J., and Greig, A.: The $4.2 \mathrm{ka}$ event in the central Mediterranean: new data from a Corchia speleothem (Apuan Alps, central Italy), Clim. Past, 15, 135-151, https://doi.org/10.5194/cp15-135-2019, 2019.

Jamieson, R. A., Baldini, J. U. L., Frappier, A. B., and Müller, W.: Volcanic ash fall events identified using principal component analysis of a high-resolution speleothem trace element dataset, Earth Planet. Sc. Lett., 426, 36-45, https://doi.org/10.1016/J.EPSL.2015.06.014, 2015.

Jex, C. N., Baker, A., Fairchild, I. J., Eastwood, W. J., Leng, M. J., Sloane, H. J., Thomas, L., and Bekaroglu, E.: Calibration of speleothem delta O-18 with instrumental climate records from Turkey, Global Planet. Change, 71, 207-217, https://doi.org/10.1016/j.gloplacha.2009.08.004, 2010.

Jex, C. N., Baker, A., Eden, J. M., Eastwood, W. J., Fairchild, I. J., Leng, M. J., Thomas, L., and Sloane, H. J.: A $500 \mathrm{yr}$ speleothem-derived reconstruction of late autumn-winter precipitation, northeast Turkey, Quaternary Res., 75, 399-405, https://doi.org/10.1016/j.yqres.2011.01.005, 2011.

Jex, C. N., Phipps, S. J., Baker, A., and Bradley, C.: Reducing uncertainty in the climatic interpretations of speleothem delta O-18, Geophys. Res. Lett., 40, 2259-2264, https://doi.org/10.1002/grl.50467, 2013.

Jiang, X., He, Y., Shen, C., Kong, X., Li, Z., and Chang, Y.: Stalagmite-inferred Holocene precipitation in northern Guizhou Province, China, and asynchronous termination of the Climatic Optimum in the Asian monsoon territory, Chinese Sci. Bull., 57, 795-801, https://doi.org/10.1007/s11434-011-4848-6, 2012.

Jiang, X., He, Y., Shen, C.-C., Li, Z., and Lin, K.: Replicated stalagmite-inferred centennial-to decadalscale monsoon precipitation variability in southwest China since the mid Holocene, Holocene, 23, 841-849, https://doi.org/10.1177/0959683612471986, 2013.

Jo, K.-n., Yi, S., Lee, J.-Y., Woo, K. S., Cheng, H., Edwards, L. R., and Kim, S.-T.: 1000-Year Quasi-Periodicity of Weak Monsoon Events in Temperate Northeast Asia since the Mid-Holocene,
Sci. Rep., 7, 15196, https://doi.org/10.1038/s41598-017-155664, 2017.

Johnson, K. R., Ingram, B. L., Sharp, W. D., and Zhang, P. Z.: East Asian summer monsoon variability during Marine Isotope Stage 5 based on speleothem $\delta^{18} \mathrm{O}$ records from Wanxiang Cave, central China, Palaeogeogr. Palaeocl., 236, 5-19, https://doi.org/10.1016/j.palaeo.2005.11.041, 2006.

Kanner, L. C., Burns, S. J., Cheng, H., and Edwards, R. L.: High-Latitude Forcing of the South American Summer Monsoon During the Last Glacial, Science, 335, 570-573, https://doi.org/10.1126/science.1213397, 2012.

Kanner, L. C., Burns, S. J., Cheng, H., Edwards, R. L., and Vuille, M.: High-resolution variability of the South American summer monsoon over the last seven millennia: insights from a speleothem record from the central Peruvian Andes, Quaternary Sci. Rev., 75, 1-10, https://doi.org/10.1016/j.quascirev.2013.05.008, 2013.

Kathayat, G., Cheng, H., Sinha, A., Yi, L., Li, X. L., Zhang, H. W., Li, H. Y., Ning, Y. F., and Edwards, R. L.: The Indian monsoon variability and civilization changes in the Indian subcontinent, Science Advances, 3, e1701296, https://doi.org/10.1126/sciadv.1701296, 2017.

Kathayat, G., Cheng, H., Sinha, A., Berkelhammer, M., Zhang, H., Duan, P., Li, H., Li, X., Ning, Y., and Edwards, R. L.: Evaluating the timing and structure of the $4.2 \mathrm{ka}$ event in the Indian summer monsoon domain from an annually resolved speleothem record from Northeast India, Clim. Past, 14, 18691879, https://doi.org/10.5194/cp-14-1869-2018, 2018.

Kaushal, N., Breitenbach, F. M. S., Lechleitner, A. F., Sinha, A., Tewari, C. V., Ahmad, M. S., Berkelhammer, M., Band, S., Yadava, M., Ramesh, R., and Henderson, M. G.: The Indian Summer Monsoon from a Speleothem $\delta^{18}$ O Perspective - A Review, Quaternary, 1, 29, https://doi.org/10.3390/quat1030029, 2018.

Kern, Z., Demény, A., Perşoiu, A., and Hatvani, G. I.: Speleothem Records from the Eastern Part of Europe and Turkey - Discussion on Stable Oxygen and Carbon Isotopes, Quaternary, 2, 31, https://doi.org/10.3390/quat2030031, 2019.

Krause, C. E., Gagan, M. K., Dunbar, G. B., Hantoro, W. S., Hellstrom, J. C., Cheng, H., Edwards, R. L., Suwargadi, B. W., Abram, N. J., and Rifai, H.: Spatio-temporal evolution of Australasian monsoon hydroclimate over the last 40,000 years, Earth Planet. Sc. Lett., 513, 103-112, https://doi.org/10.1016/J.EPSL.2019.01.045, 2019.

Lachniet, M. S., Asmerom, Y., Burns, S. J., Patterson, W. P., Polyak, V. J., and Seltzer, G. O.: Tropical response to the 8200 yr BP cold event? Speleothem isotopes indicate a weakened early Holocene monsoon in Costa Rica, Geology, 32, 957-960, https://doi.org/10.1130/g20797.1, 2004.

Lachniet, M. S., Johnson, L., Asmerom, Y., Burns, S. J., Polyak, V., Patterson, W. P., Burt, L., and Azouz, A.: Late Quaternary moisture export across Central America and to Greenland: evidence for tropical rainfall variability from Costa Rican stalagmites, Quaternary Sci. Rev., 28, 3348-3360, https://doi.org/10.1016/J.QUASCIREV.2009.09.018, 2009.

Laskar, A. H., Yadava, M. G., Ramesh, R., Polyak, V. J., and Asmerom, Y.: A $4 \mathrm{kyr}$ stalagmite oxygen isotopic record of the past Indian Summer Monsoon in the Andaman Islands, Geochem., Geophy., Geosy., 14, 3555-3566, https://doi.org/10.1002/ggge.20203, 2013. 
Lauritzen, S.-E., and Onac, B. P.: Isotopic Stratigraphy of a Last Interglacial Stalagmite from Northwestern Romania: Correlation with the Deep-Sea record and Northern-Latitude Speleothem, J. Cave Karst Stud., 61, 22-30, 1999.

Lechleitner, F. A., Amirnezhad-Mozhdehi, S., Columbu, A., Comas-Bru, L., Labuhn, I., Pérez-Mejías, C., and Rehfeld, K.: The Potential of Speleothems from Western Europe as Recorders of Regional Climate: A Critical Assessment of the SISAL Database, Quaternary, 1, 30, https://doi.org/10.3390/quat1030030, 2018.

Li, H., Cheng, H., Sinha, A., Kathayat, G., Spötl, C., André, A. A., Meunier, A., Biswas, J., Duan, P., Ning, Y., and Edwards, R. L.: Hydro-climatic variability in the southwestern Indian Ocean between 6000 and 3000 years ago, Clim. Past, 14, 1881-1891, https://doi.org/10.5194/cp-14-1881-2018, 2018.

Liu, X., Rao, Z., Shen, C. C., Liu, J., Chen, J., Chen, S., Wang, X., and Chen, F.: Holocene Solar Activity Imprint on Centennial- to Multidecadal-Scale Hydroclimatic Oscillations in Arid Central Asia, J. Geophys. Res.-Atmos., 124, 2562-2573, https://doi.org/10.1029/2018JD029699, 2019.

Logan, A. J.: A new paleoclimate record for North Westland, New Zealand, with implications for the interpretation of speleothem based paleoclimate proxies, Master of Science, Geology, University of Canterbury, 109 pp., available at: http://hdl.handle.net/ 10092/5762 (last access: 31 January 2020), 2011.

Lončar, N., Bar-Matthews, M., Ayalon, A., Faivre, S., and Surić, M.: Holocene climatic conditions in the eastern Adriatic recorded in stalagmites from Strašna peć Cave (Croatia), Quatern. Int., 508, 98-106, https://doi.org/10.1016/j.quaint.2018.11.006, 2019.

Lorrey, A., Williams, P., Salinger, J., Martin, T., Palmer, J., Fowler, A., Zhao, J.-x., and Neil, H.: Speleothem stable isotope records interpreted within a multi-proxy framework and implications for New Zealand palaeoclimate reconstruction, Quatern. Int., 187, 52-75, https://doi.org/10.1016/j.quaint.2007.09.039, 2008.

Lorrey, A. M., Vandergoes, M., Renwick, J., Newnham, R., Ackerley, D., Bostock, H., Williams, P. W., King, D. N. T., Neil, H., Harper, S., et al.: A Regional Climate Regime Classification Synthesis for New Zealand Covering Three Critical Periods of the Late Quaternary: The Last 2000 Years, the Mid-Holocene, and the End of the Last Glacial Coldest Period; NIWA Client Report AKL2010-025; National Institute of Water and Atmospheric Research Ltd., Auckland, New Zealand, 2010.

Marsh, A., Fleitmann, D., Al-Manmi, D. A. M., Altaweel, M., Wengrow, D., and Carter, R.: Mid- to late-Holocene archaeology, environment and climate in the northeast Kurdistan region of Iraq, Holocene, 28, 955-967, https://doi.org/10.1177/0959683617752843, 2018.

McCabe-Glynn, S., Johnson, K. R., Strong, C., Berkelhammer, M., Sinha, A., Cheng, H., and Edwards, R. L.: Variable North Pacific influence on drought in southwestern North America since AD 854, Nat. Geosci., 6, 617-621, https://doi.org/10.1038/ngeo1862, 2013.

Medina-Elizalde, M., Burns, S. J., Polanco-Martinez, J. M., Beach, T., Lases-Hernandez, F., Shen, C. C., and Wang, H. C.: High-resolution speleothem record of precipitation from the Yucatan Peninsula spanning the Maya Preclassic Period, Global Planet. Change, 138, 93-102, https://doi.org/10.1016/j.gloplacha.2015.10.003, 2016.
Medina-Elizalde, M., Burns, S. J., Polanco-Martinez, J., LasesHernandez, F., Bradley, R., Wang, H. C., and Shen, C. C.: Synchronous precipitation reduction in the American Tropics associated with Heinrich 2, Sci. Rep., 7, 11216, https://doi.org/10.1038/s41598-017-11742-8, 2017.

Moseley, G. E., Spötl, C., Brandstätter, S., Erhardt, T., Luetscher, M., and Edwards, R. L.: NALPS19: sub-orbitalscale climate variability recorded in northern Alpine speleothems during the last glacial period, Clim. Past, 16, 29-50, https://doi.org/10.5194/cp-16-29-2020, 2020.

Mudelsee, M., Fohlmeister, J., and Scholz, D.: Effects of dating errors on nonparametric trend analyses of speleothem time series, Clim. Past, 8, 1637-1648, https://doi.org/10.5194/cp-81637-2012, 2012.

Niggemann, S., Mangini, A., Mudelsee, M., Richter, D. K., and Wurth, G.: Sub-Milankovitch climatic cycles in Holocene stalagmites from Sauerland, Germany, Earth Planet. Sc. Lett., 216, 539-547, https://doi.org/10.1016/S0012-821X(03)00513-2, 2003a.

Niggemann, S., Mangini, A., Richter, D. K., and Wurth, G.: A paleoclimate record of the last 17,600 years in stalagmites from the B7 cave, Sauerland, Germany, Quaternary Sci. Rev., 22, 555567, https://doi.org/10.1016/s0277-3791(02)00143-9, 2003b.

Osete, M. L., Martin-Chivelet, J., Rossi, C., Edwards, R. L., Egli, R., Munoz-Garcia, M. B., Wang, X. F., PavonCarrasco, F. J., and Heller, F.: The Blake geomagnetic excursion recorded in a radiometrically dated speleothem, Earth Planet. Sc. Lett., 353, 173-181, https://doi.org/10.1016/j.eps1.2012.07.041, 2012.

Oster, J. L., Warken, S. F., Sekhon, N., Arienzo, M., and Lachniet, M.: Speleothem Paleoclimatology for the Caribbean, Central America, and North America, Quaternary, 2, 5, https://doi.org/10.3390/quat2010005, 2019.

Parnell, A.: Bchron: Radiocarbon dating, age-depth modelling, relative sea level rate estimation, and non-parametric phase modelling, R package version 4.3.0, 2018.

Partin, J. W., Quinn, T. M., Shen, C. C., Okumura, Y., Cardenas, M. B., Siringan, F. P., Banner, J. L., Lin, K., Hu, H. M., and Taylor, F. W.: Gradual onset and recovery of the Younger Dryas abrupt climate event in the tropics, Nat. Commun., 6, 8061-8061, https://doi.org/10.1038/ncomms9061, 2015.

Pawlak, J., Błaszczyk, M., Hercman, H., and Matoušková, Š.: A continuous stable isotope record of last interglacial age from the Bulgarian Cave Orlova Chuka, Geochronometria, 46, 87-101, https://doi.org/10.1515/geochr-2015-0107, 2019.

Peckover, E. N., Andrews, J. E., Leeder, M. R., Rowe, P. J., Marca, A., Sahy, D., Noble, S., and Gawthorpe, R.: Coupled stalagmite - Alluvial fan response to the $8.2 \mathrm{ka}$ event and early Holocene palaeoclimate change in Greece, Palaeogeogr. Palaeocl., 532, 109252-109252, https://doi.org/10.1016/j.palaeo.2019.109252, 2019.

Polyak, V. J., Asmerom, Y., and Lachniet, M. S.: Rapid speleothem $\delta^{13} \mathrm{C}$ change in southwestern North America coincident with Greenland stadial 20 and the Toba (Indonesia) supereruption, Geology, 45, 843-846, https://doi.org/10.1130/g39149.1, 2017.

R Core Team: R: A language and environment for statistical computing, R Foundation for Statistical Computing, Vienna, Austria, available at: http://www.r-project.org/index.html (last access: 31 January 2020), 2019. 
Rehfeld, K. and Kurths, J.: Similarity estimators for irregular and age-uncertain time series, Clim. Past, 10, 107-122, https://doi.org/10.5194/cp-10-107-2014, 2014.

Rehfeld, K., Goswami B., Juncu, D. Marwan N., and Breitenbach, S.: COPRA - Constructing Proxy Records From Age Models, Version 1.15, last mod. 2 November 2017, available at: https://tocsy.pik-potsdam.de/copra.php (last access: 31 January 2020), 2017.

Rehfeld, K., Roesch, C., Comas-Bru, L., and AmirnezhadMozhdehi, S.: Age-depth model ensembles for SISAL v2 speleothem records (Version 1.0), Data set, Zenodo, https://doi.org/10.5281/zenodo.3816804, 2020.

Rivera-Collazo, I., Winter, A., Scholz, D., Mangini, A., Miller, T., Kushnir, Y., and Black, D.: Human adaptation strategies to abrupt climate change in Puerto Rico ca. 3.5 ka, Holocene, 25, 627-640, https://doi.org/10.1177/0959683614565951, 2015.

Roesch, C. and Rehfeld, K.: Automatising construction and evaluation of age-depth models for hundreds of speleothems, 9th International Workshop on Climate Informatics, Paris, France, 2-4 October, 2019.

Rossi, C., Mertz-Kraus, R., and Osete, M. L.: Paleoclimate variability during the Blake geomagnetic excursion (MIS 5d) deduced from a speleothem record, Quaternary Sci. Rev., 102, 166-180, https://doi.org/10.1016/j.quascirev.2014.08.007, 2014.

Rossi, C., Bajo, P., Lozano, R. P., and Hellstrom, J.: Younger Dryas to Early Holocene paleoclimate in Cantabria (N Spain): Constraints from speleothem $\mathrm{Mg}$, annual fluorescence banding and stable isotope records, Quaternary Sci. Rev., 192, 71-85, https://doi.org/10.1016/j.quascirev.2018.05.025, 2018.

Rudzka, D., McDermott, F., and Suric, M.: A late Holocene climate record in stalagmites from Modric Cave (Croatia), J. Quaternary Sci., 27, 585-596, https://doi.org/10.1002/jqs.2550, 2012.

Rudzka-Phillips, D., McDermott, F., Jackson, A., and Fleitmann, D.: Inverse modelling of the C-14 bomb pulse in stalagmites to constrain the dynamics of soil carbon cycling at selected European cave sites, Geochim. Cosmochim. Ac., 112, 32-51, https://doi.org/10.1016/j.gca.2013.02.032, 2013.

Scholz, D. and Hoffmann, D. L.: StalAge - An algorithm designed for construction of speleothem age models, Quat. Geochronol., 6, 369-382, https://doi.org/10.1016/j.quageo.2011.02.002, 2011.

Scroxton, N., Burns, S. J., McGee, D., Hardt, B., Godfrey, L. R., Ranivoharimanana, L., and Faina, P.: Competing Temperature and Atmospheric Circulation Effects on Southwest Madagascan Rainfall During the Last Deglaciation, Paleoceanogr. Paleocl., 34, 275-286, https://doi.org/10.1029/2018PA003466, 2019.

Sinha, N., Gandhi, N., Chakraborty, S., Krishnan, R., Yadava, M. G., and Ramesh, R.: Abrupt climate change at $\sim 2800$ yr BP evidenced by a stalagmite record from peninsular India, Holocene, 28, 1720-1730, https://doi.org/10.1177/0959683618788647, 2018.

Staubwasser, M., Drăguşin, V., Onac, B. P., Assonov, S., Ersek, V., Hoffmann, D. L., and Veres, D.: Impact of climate change on the transition of Neanderthals to modern humans in Europe, P. Natl. Acad. Sci. USA, 115, 9116-9121, https://doi.org/10.1073/pnas.1808647115, 2018.

Steponaitis, E., Andrews, A., McGee, D., Quade, J., Hsieh, Y. T., Broecker, W. S., Shuman, B. N., Burns, S. J., and Cheng, H.: Mid-Holocene drying of the US Great Basin recorded in
Nevada speleothems, Quaternary Sci. Rev., 127, 174-185, https://doi.org/10.1016/j.quascirev.2015.04.011, 2015.

Strikis, N. M., Chiessi, C. M., Cruz, F. W., Vuille, M., Cheng, H., Barreto, E. A. D., Mollenhauer, G., Kasten, S., Karmann, I., Edwards, R. L., Bernal, J. P., and Sales, H. D.: Timing and structure of Mega-SACZ events during Heinrich Stadial 1, Geophys. Res. Lett., 42, 5477-5484, https://doi.org/10.1002/2015gl064048, 2015.

Stríkis, N. M., Cruz, F. W., Barreto, E. A. S., Naughton, F., Vuille, M., Cheng, H., Voelker, A. H. L., Zhang, H., Karmann, I., Edwards, R. L., Auler, A. S., Santos, R. V., and Sales, H. R.: South American monsoon response to iceberg discharge in the North Atlantic, P. Natl. Acad. Sci. USA, 115, 37883793, https://doi.org/10.1073/pnas.1717784115, 2018.

Talma, A. S. and Vogel, J. C.: Late Quaternary Paleotemperatures Derived from a Speleothem from Cango Caves, Cape Province, South Africa, Quaternary Res., 37, 203-213, https://doi.org/10.1016/0033-5894(92)90082-t, 1992.

Tan, L., An, Z., Huh, C.-A., Cai, Y., Shen, C.-C., Shiau, L.J., Yan, L., Cheng, H., and Edwards, R. L.: Cyclic precipitation variation on the western Loess Plateau of China during the past four centuries, Sci. Rep., 4, 6381-6381, https://doi.org/10.1038/srep06381, 2015.

Tan, L., Cai, Y., Cheng, H., Edwards, L. R., Gao, Y., Xu, H., Zhang, H., and An, Z.: Centennial- to decadal-scale monsoon precipitation variations in the upper Hanjiang River region, China over the past 6650 years, Earth Planet. Sc. Lett., 482, 580590, https://doi.org/10.1016/j.eps1.2017.11.044, 2018a.

Tan, L., Cai, Y., Cheng, H., Edwards, L. R., Lan, J., Zhang, H., Li, D., Ma, L., Zhao, P., and Gao, Y.: High resolution monsoon precipitation changes on southeastern Tibetan Plateau over the past 2300 years, Quaternary Sci. Rev., 195, 122-132, https://doi.org/10.1016/J.QUASCIREV.2018.07.021, 2018b.

Tzedakis, P. C., Drysdale, R. N., Margari, V., Skinner, L. C., Menviel, L., Rhodes, R. H., Taschetto, A. S., Hodell, D. A., Crowhurst, S. J., Hellstrom, J. C., Fallick, A. E., Grimalt, J. O., McManus, J. F., Martrat, B., Mokeddem, Z., Parrenin, F., Regattieri, E., Roe, K., and Zanchetta, G.: Enhanced climate instability in the North Atlantic and southern Europe during the Last Interglacial, Nat. Commun., 9, 4235-4235, https://doi.org/10.1038/s41467-018-06683-3, 2018.

van Breukelen, M. R., Vonhof, H. B., Hellstrom, J. C., Wester, W. C. G., and Kroon, D.: Fossil dripwater in stalagmites reveals Holocene temperature and rainfall variation in Amazonia, Earth Planet. Sc. Lett., 275, 54-60, https://doi.org/10.1016/J.EPSL.2008.07.060, 2008.

Van Rampelbergh, M., Fleitmann, D., Verheyden, S., Cheng, H., Edwards, L., De Geest, P., De Vleeschouwer, D., Burns, S. J., Matter, A., Claeys, P., and Keppens, E.: Mid- to late Holocene Indian Ocean Monsoon variability recorded in four speleothems from Socotra Island, Yemen, Quaternary Sci. Rev., 65, 129-142, https://doi.org/10.1016/j.quascirev.2013.01.016, 2013.

Verheyden, S., Keppens, E., Fairchild, I. J., McDermott, F., and Weis, $\mathrm{D}$.: $\mathrm{Mg}, \mathrm{Sr}$ and $\mathrm{Sr}$ isotope geochemistry of a Belgian Holocene speleothem: implications for paleoclimate reconstructions, Chem. Geol., 169, 131-144, https://doi.org/10.1016/s0009-2541(00)00299-0, 2000.

Verheyden, S., Keppens, E., Quinif, Y., Cheng, H. J., and Edwards, L. R.: Late-glacial and Holocene climate reconstruc- 
tion as inferred from a stalagmite-Grotte du Père Noël, Hansur-Lesse, Belgium, Geol. Belg., 17, 83-89, available at: https: //popups.uliege.be:443/1374-8505/index.php?id=4412 (last access: 31 January 2020), 2014.

Wang, J. K., Johnson, K. R., Borsato, A., Amaya, D. J., Griffiths, M. L., Henderson, G. M., Frisia, S., and Mason, A.: Hydroclimatic variability in Southeast Asia over the past two millennia, Earth Planet. Sc. Lett., 525, 115737-115737, https://doi.org/10.1016/j.epsl.2019.115737, 2019.

Wang, Y. J., Cheng, H., Edwards, R. L., Kong, X. G., Shao, X. H., Chen, S. T., Wu, J. Y., Jiang, X. Y., Wang, X. F., and An, Z. S.: Millennial- and orbital-scale changes in the East Asian monsoon over the past 224,000 years, Nature, 451, 1090-1093, https://doi.org/10.1038/nature06692, 2008.

Ward, B. M., Wong, C. I., Novello, V. F., McGee, D., Santos, R. V., Silva, L. C. R., Cruz, F. W., Wang, X., Edwards, R. L., and Cheng, H.: Reconstruction of Holocene coupling between the South American Monsoon System and local moisture variability from speleothem $\delta^{18} \mathrm{O}$ and ${ }^{87} \mathrm{Sr} /{ }^{86} \mathrm{Sr}$ records, Quaternary Sci. Rev., 210, 51-63, https://doi.org/10.1016/J.QUASCIREV.2019.02.019, 2019.

Warken, S. F., Fohlmeister, J., Schröder-Ritzrau, A., Constantin, S., Spötl, C., Gerdes, A., Esper, J., Frank, N., Arps, J., Terente, M., Riechelmann, D. F. C., Mangini, A. and Scholz, D.: Reconstruction of late Holocene autumn/winter precipitation variability in SW Romania from a high-resolution speleothem trace element record, Earth Planet. Sc. Lett., 499, 122-133, https://doi.org/10.1016/j.epsl.2018.07.027, 2018.

Warken, S. F., Scholz, D., Spötl, C., Jochum, K. P., Pajón, J. M., Bahr, A., and Mangini, A.: Caribbean hydroclimate and vegetation history across the last glacial period, Quaternary Sci.. Rev., 218, 75-90, https://doi.org/10.1016/J.QUASCIREV.2019.06.019, 2019.

Webb, M., Dredge, J., Barker, P. A., Muller, W., Jex, C., Desmarchelier, J., Hellstrom, J., and Wynn, P. M.: Quaternary climatic instability in south-east Australia from a multiproxy speleothem record, J. Quaternary Sci., 29, 589-596, https://doi.org/10.1002/jqs.2734, 2014.

Weber, M., Scholz, D., Schröder-Ritzrau, A., Deininger, M., Spötl, C., Lugli, F., Mertz-Kraus, R., Jochum, K. P., Fohlmeister, J., Stumpf, C. F., and Riechelmann, D. F. C.: Evidence of warm and humid interstadials in central Europe during early MIS 3 revealed by a multi-proxy speleothem record, Quaternary Sci. Rev., 200, 276-286, https://doi.org/10.1016/J.QUASCIREV.2018.09.045, 2018.

Wendt, K. A., Häuselmann, A. D., Fleitmann, D., Berry, A. E., Wang, X., Auler, A. S., Cheng, H., and Edwards, R. L.: Three-phased Heinrich Stadial 4 recorded in NE Brazil stalagmites, Earth Planet. Sc. Lett., 510, 94-102, https://doi.org/10.1016/J.EPSL.2018.12.025, 2019.

Whittaker, T. E.: High-resolution speleothem-based palaeoclimate records from New Zealand reveal robust teleconnection to North Atlantic during MIS 1-4, unpublished PhD Thesis, The University of Waikato, 2008.

Wilcox, P. S., Dorale, J. A., Baichtal, J. F., Spötl, C., Fowell, S. J., Edwards, R. L., and Kovarik, J. L.: Millennialscale glacial climate variability in Southeastern Alaska follows Dansgaard-Oeschger cyclicity, Sci. Rep., 9, 7880-7880, https://doi.org/10.1038/s41598-019-44231-1, 2019.
Williams, P. W., King, D. N. T., Zhao, J. X., and Collerson, K. D.: Late pleistocene to holocene composite speleothem O-18 and C-13 chronologies from south island, new Zealand-did a global younger dryas really exist?, Earth Planet. Sc. Lett., 230, 301317, https://doi.org/10.1016/j.epsl.2004.10.024, 2005.

Williams, P. W., Neil, H. L., and Zhao, J. X.: Age frequency distribution and revised stable isotope curves for New Zealand speleothems: palaeoclimatic implications, Int. J. Speleol., 39, 99-112, https://doi.org/10.5038/1827-806x.39.2.5, 2010.

Wu, J. Y., Wang, Y. J., Cheng, H., Kong, X. G., and Liu, D. B.: Stable isotope and trace element investigation of two contemporaneous annually-laminated stalagmites from northeastern China surrounding the "8.2 ka event", Clim. Past, 8, 1497-1507, https://doi.org/10.5194/cp-8-1497-2012, 2012.

Yadava, M. G., Ramesh, R., and Pant, G. B.: Past monsoon rainfall variations in peninsular India recorded in a 331-year-old speleothem, Holocene, 14, 517-524, https://doi.org/10.1191/0959683604hl728rp, 2004.

Yin, J. J., Li, H. C., Rao, Z. G., Shen, C. C., Mii, H. S., Pillutla, R. K., Hu, H. M., Li, Y. X., and Feng, X. H.: Variations of monsoonal rain and vegetation during the past millennium in Tiangui Mountain, North China reflected by stalagmite delta O-18 and delta C-13 records from Zhenzhu Cave, Quatern. Int., 447, 89-101, https://doi.org/10.1016/j.quaint.2017.06.039, 2017.

Zhang, H., Cheng, H., Cai, Y., Spötl, C., Kathayat, G., Sinha, A., Edwards, R. L., and Tan, L.: Hydroclimatic variations in southeastern China during the $4.2 \mathrm{ka}$ event reflected by stalagmite records, Clim. Past, 14, 1805-1817, https://doi.org/10.5194/cp14-1805-2018, 2018a.

Zhang, H., Cheng, H., Spötl, C., Cai, Y., Sinha, A., Tan, L., Yi, L., Yan, H., Kathayat, G., Ning, Y., Li, X., Zhang, F., Zhao, J., and Edwards, R. L.: A 200-year annually laminated stalagmite record of precipitation seasonality in southeastern China and its linkages to ENSO and PDO, Sci. Rep., 8, 12344-12344, https://doi.org/10.1038/s41598-018-30112-6, 2018b.

Zhang, H., Ait Brahim, Y., Li, H., Zhao, J., Kathayat, G., Tian, Y., Baker, J., Wang, J., Zhang, F., Ning, Y., Edwards, L. R., and Cheng, H.: The Asian Summer Monsoon: Teleconnections and Forcing Mechanisms - A Review from Chinese Speleothem $\delta^{18} \mathrm{O}$ Records, Quaternary, 2, 26, https://doi.org/10.3390/quat2030026, 2019.

Zhang, H. B., Griffiths, M. L., Huang, J. H., Cai, Y. J., Wang, C. F., Zhang, F., Cheng, H., Ning, Y. F., Hu, C. Y., and Xie, S. C.: Antarctic link with East Asian summer monsoon variability during the Heinrich Stadial-Bølling interstadial transition, Earth Planet. Sc. Lett., 453, 243-251, https://doi.org/10.1016/j.epsl.2016.08.008, 2016.

Zhang, H. L., Yu, K. F., Zhao, J. X., Feng, Y. X., Lin, Y. S., Zhou, W., and Liu, G. H.: East Asian Summer Monsoon variations in the past $12.5 \mathrm{ka}$ : High-resolution $\delta^{18} \mathrm{O}$ record from a precisely dated aragonite stalagmite in central China, J. Asian Earth Sci., 73, 162-175, https://doi.org/10.1016/j.jseaes.2013.04.015, 2013.

Zhang, P., Cheng, H., Edwards, R. L., Chen, F., Wang, Y., Yang, X., Liu, J., Tan, M., Wang, X., Liu, J., An, C., Dai, Z., Zhou, J., Zhang, D., Jia, J., Jin, L., and Johnson, K. R.: A Test of Climate, Sun, and Culture Relationships from 
an 1810-Year Chinese Cave Record, Science, 322, 940-942, https://doi.org/10.1126/science.1163965, 2008. 